\section{KOMULAKASI KRTIS \& ANGMMAN ROAKS}

Buku referensi ini adalah telsah kritis secara akademis dalam memahami komunikasi dan berbagai fenomena hoaks yang tesjadi ditengah masyarakat. Disadari bahwa perkembangan teknologi informasi internet mengakibatkan informasi melaju dengan sangat cepat dan masif. Alhasil bermunculan informasi yang tidak benar atau abal-abal / hoaks tidak bisa hindari. Budaya masyarakat yang mudah percaya dan cenderung membagikan informasi tanpa melakukan screening pada kelompok komunitas maupun organisas liannya adalah masalah sosial yang sangat jamak. Informasi tersebut berkembang di berbagai media saat ini, Khususnya media-media online yang "berhamburan' di dunia maya. Belum lagi ditambah dengan aplikasi platform media sosial sekarang ini yang sangat mudah diakses dan selalu update teknologinya dari waktu ke waktu Media sosial tersebut memiliki anekn ragam ienianya. Seperti twitter,facebook, instapram, podeast dan yang lain. Apalagi mediamedia itu sangat familiar dengan berbagailkalangan: (Triyono, 2020).

Dari hal itulah, penulis mencoba menggall dan menganalisis is: dari konten-konten informasi hoaks dari berbagai platform media sosial seperti youtube, whatsapp, facebook, instagram dan yang lain. Konten isi tersebut dianalisis berdasarkan kajian akademis dan menghasilkan temuan yang dapat memberikan perspekat dalam berpilcir. Buku ini juga memberikan solust atas permasalahan hoaks yang terjadi selama ini. Banyak hal yang bisa dilakukan dalam mengantisipasi dan mengatasi timbulnya hoaks. Bengan program dan formula yang mudah dipahami, buku ini dapat dijadikan bahan rujukan dan diskusi dalam memahami kajian tentang hoaks dan permasalahannya seiring perkembangan waktu dan perkembangan teknologinformagi

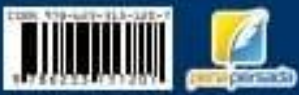

Dr. Agus Triyono, MSi

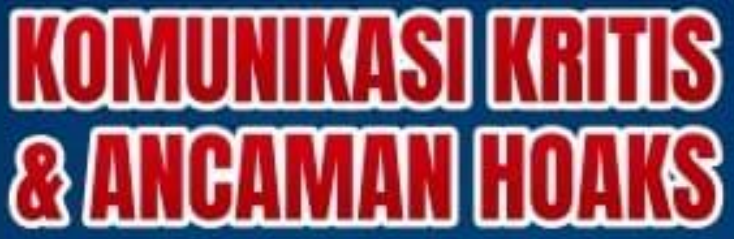

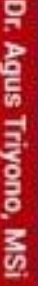

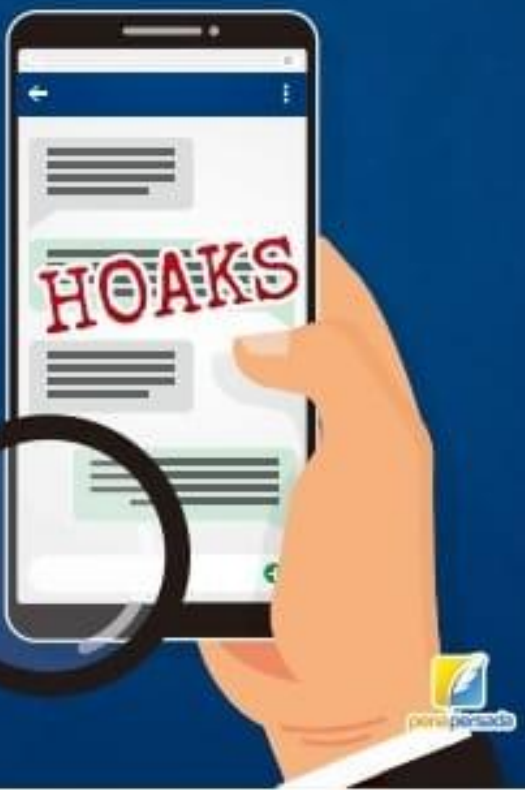


KOMUNIKASI KRITIS \& ANCAMAN HOAKS

Dr. Agus Triyono, M.Si.

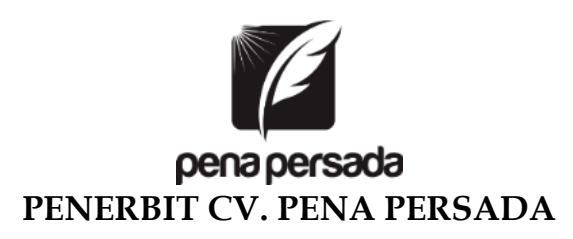




\title{
KOMUNIKASI KRITIS \& ANCAMAN HOAKS
}

\author{
Penulis: \\ Dr. Agus Triyono, M.Si. \\ ISBN : 978-623-315-120-7 \\ Design Cover : \\ Retnani Nur Briliant \\ Layout : \\ Nisa Falahia \\ Penerbit CV. Pena Persada \\ Redaksi : \\ Jl. Gerilya No. 292 Purwokerto Selatan, Kab. Banyumas \\ Jawa Tengah \\ Email : penerbit.penapersada@gmail.com \\ Website : penapersada.com Phone : (0281) 7771388 \\ Anggota IKAPI \\ All right reserved \\ Cetakan pertama : 2020
}

Hak Cipta dilindungi oleh undang-undang. Dilarang memperbanyak karya tulis ini dalam bentuk apapun tanpa izin penerbit 


\section{KATA PENGANTAR}

\section{Bismillahirrahmanirrahim}

\section{Assalamualaikum wa Rahmatullah wa Barakatuh}

Saya ucapkan terima kasih yang tak terhingga pada Allah SWT atas selesainya pembuatan buku referensi ini dengan judul "Komunikasi Kritis \& Ancaman Hoaks"

Buku ini adalah hasil dari telaah kritis atas permasalahan hoaks yang beredar di tengah masyarakat dari berbagai sektor kehidupan. Mulai dari kehidupan sosial, politik hingga kesehatan di masa pandemi yang tengah melanda negeri ini. Struktur buku ini dibuat sebagai buku referensi karena pembahasannya pada satu bidang ilmu kompetensi penulis yakni tentang berita atau informasi khususnya hoaks. Isi buku ini terdiri dari rumusan masalah yang mengandung kebaruan (novelty), metodologi pemecahan masalah, dukungan data yang jelas, serta adanya kesimpulan dan daftar pustaka yang menunjukkan rekam jejak penulis. Buku ini merupakan salah satu alternatif dalam memberikan solusi permasalahan terhadap fenomena hoaks yang berpengaruh pada kehidupan masyarakat.

Apresiasi terindah dan rasa terimakasih ditujukan kepada Susi Hariyani, Triple A (Adham,Abin,Aleena) sebagai sumber motivasi terbesar dalam menyusun buku ini.

Ucapan terimakasih juga pada rekan-rekan dan semua pihak pihak yang telah ikut membantu dalam penyelesaian buku ini.

Saya menyadari masih terdapat banyak kekurangan dalam buku ini. Kritik dan saran terhadap penyempurnaan buku ini sangat diharapkan. Semoga buku ini dapat memberi maanfaat bagi semua pihak yang membutuhkan.

Wassalamualaikum wa Rahmatullah wa Barakatuh

Semarang, Desember 2020

Agus Triyono 


\section{DAFTAR ISI}

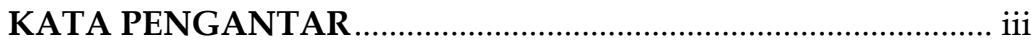

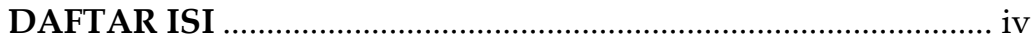

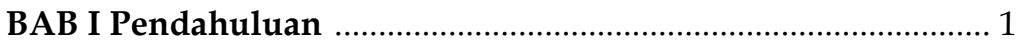

BAB II Rumusan Masalah dan Kebaruan ................................. 4

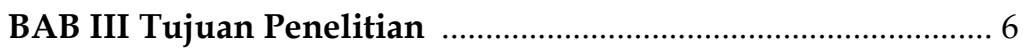

BAB IV Metodologi Pemecahan Masalah …………………......... 7

BAB V Teori \& Tinjauan Pustaka ………………........................... 12

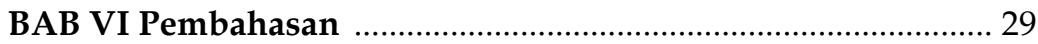

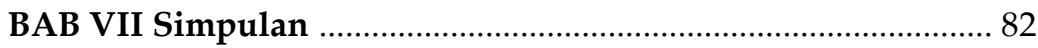

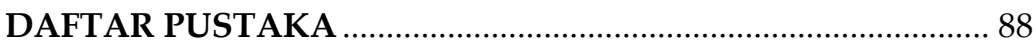

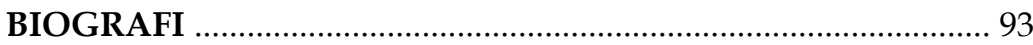




\section{BAB I \\ PENDAHULUAN}

Hoak adalah informasi yang tidak benar, tidak berdasarkan fakta. Bisa juga berupa berita palsu atau bohong yang sengaja disebarluaskan pada masyarakat. Menurut Kamus,Besar Bahasa Indonesia (KBBI), hoaks berarti "berita bohong". Hoak yaitu ekses negatif kebebasan berbicara dan berpendapat di internet, khususnya melalui media media sosial. Sedangkan menurut wikipedia, hoak ialah usaha untuk menipu atau mengakali pembaca/pendengarnya untuk mempercayai sesuatu.

Hoak bertujuan, untuk membuat opini publik melalui penggiringan opini, pembentukan persepsi, dan juga untuk melakukan kesenangan dengan pengujian kecerdasan, dan kecermatan pengguna internet, dan media sosial. Berkembangnya hoak, dilakukan oleh oknum orang atau sebuah kelompok dengan banyak tujuan. Ada yang berawal dari "iseng", hingga tujuan melakukan tipu daya, dan politisasi, pembentukan opini publik atau agitasi atau hasutan. Hoak biasanya muncul ketika sebuah isu mencuat ke permukaan. Namun banyak hal yang belum terungkap atau menjadi tanda tanya. Di Indonesia, hoak sebenarnya sudah terjadi, sekian lama. Namun, baru melonjak naik dan ramai menjadi konsumsi publik saat pilpres "presiden 2014" sebagai akibat maraknya kampanye di media sosial. Pada waktu itu hoak bermunculan agar mampu menurunkan citra lawan politiknya atau melakukan kampanye negatif. Menurut Dewan-Pers, di Indonesia maraknya hoak juga karena adanya krisis kepercayaan terhadap media mainstream sehingga publik menjatuhkan ke media abal-abal. Apalagi saat ini, media online juga memberi ruang pada publik untuk memberikan kontribusi informasi dari warga masyarakat dalam bentuk jurnalisme warga (Triyono,2019;223). Oleh karenanya, media online kini terus berkembang masif. 
Data Dewan-pers media online pada tahun 2020 mencapai lebih dari 47 ribu. Apalagi jika kita melihat jumlah media online saat ini berkembang di daerah-daerah. Tak jarang silih berganti "bak jamur yang tumbuh di musim hujan". Hadirnya mediamedia tersebut juga berpengaruh terhadap kemajuan bidang jurnalistik. Apalagi media jenis ini, memiliki space yang sangat luas untuk mengisi konten pemberitaannya. Oleh karenanya, banyak rubrik-rubrik yang dibuat oleh media ini untuk menyalurkan beritanya secara khusus.(Triyono,2018;4)

Banyak media online sebenarnya memberikan ruang dalam rangka menyampaikan informasi yang seluas-luasnya. Namun demikian, tak jarang pula karena kondisi tertentu jumlahnya mengalami kenaikan dan penurunan seiring perkembangan jaman. Kalau kita lihat data pada tahun ini jumlah media online yang sudah terverifikasi mencapai angka 300 media. Artinya berbanding terbalik dengan media yang belum terverfikasi yang jumlahnya masih ribuan.

Seiring berkembangnya media itu, kini berkembang pula media sosial (social media) yang mewarnai kasanah dunia informasi. Media itu juga sangat update menjadi kekuatan sosial dalam menyampaikan informasi. Diakui bahwa, media ini hadir memiliki berbagai fenomena yang timbul dalam kehidupan masyarakat. Termasuk didalamnya adalah ada nilai positif dan negatif. Nilai positinya adalah bahwa media ini mampu memberikan informasi dengan cepat tanpa kendala berarti. Tanpa mempertimbangkan jarak dimana mereka tinggal, kapan akan menyampaikan atau menerima informasi, dalam kondisi apapun. Dan berbagai faktor lainnya yang terkait dengan proses alur komunikasi penyampaian pesan. Sejauh mereka memiliki jaringan dan akses internet, informasi akan dapat diakses dengan mudah dan cepat. Nilai positif yang lain adalah melalui media sosial ini seseorang akan mudah mengaktualisasikan dirinya dengan berbagai platform yang dikehendaki. Mulai dari facebook, instagram, twitter, whatsapp, tik tok dll. Media ini juga mampu 
menyatukan berbagai kolega, kawan lama, komunitas atau organisasi lainnya yang tidak pernah bertemu untuk periode waktu yang lama dapat bertemu kembali meski melalui media sosial. Mereka dapat saling berbagi informasi dan berdiskusi di media itu dengan memanfaatkan teknologi internet.

Namun demikian, pada masa kini media ini tidak hanya sebagai ruang berbagi tetapi juga ruang interaksi diantara mereka. Oleh karenanya dibutuhkan skill atau kemampuan dalam memahami media sosial secara baik. Memahami media sosial menjadi sangat penting karena pada masa ini mayoritas pengguna internet melalui media sosial memili ketergantungan yang tinggi dalam menggunakannya. Data menunjukkan rata-rata 8 jam perhari masyarakat mengakses internet (Mafindo,2020). Ini menjadi angka yang sangat tinggi dan perlu mendapat perhatian serius. Oleh karenanya diperlukan pondasi yang kuat dalam mengatasi hal ini. Salah satunya adalah dengan membuka pikiran kita terbuka secara luas (open mind). Ditambah dengan penguatan kecerdasan emosional dalam diri seseorang, sehingga dapat memaknai pentingnya kompetensi diri dalam memahami media sosial. Apalagi dalam revolusi industri 4.0 yang menggabungkan teknologi otomatis dengan dunia cyber ini membutuhkan kecerdasan baru melalui digital inteligent di era new media.

Namun, media ini juga memiliki nilai negatif yang memberi dampak buruk bagi penggunanya dan juga bagi mereka yang terdampak melalui unggahan orang lain.

Salah satu dampak negatif adalah media ini digunakan untuk kepentingan yang tidak baik. Apalagi digunakan untuk menyebarkan informasi yang tidak benar atau abal-abal alias hoak. 


\section{BAB II \\ RUMUSAN MASALAH}

Kebaruan atau novelty dari penelitian ini adalah dilakukan pada masa pandemi dan pada tahun politik tahun 2020. Begitu banyaknya hoaks yang beredar ditengah masyarakat. Hoaks ini berkembang pesat bak jamur dimusim hujan dan dari waktu kewaktu selalu mengalami peningkatan yang signifikan. Hoaks berkembang diberbagai lini kehidupan. Ironisnya secara masif menunjukkan kenaikan cukup besar yang dilandasi oleh sebuah fenomena yang jarang terjadi yakni masa pandemi. Masa dimana masyarakat dunia umumnya, dan Indonesia khususnya dilanda pandemi yang luar biasa dengan wabah COVID-19. Disamping melumpuhkan sendi-sendi kehidupan seperti sektor ekonomi, sosial, pendidikan dan sektor-sektor lainnya. Terlebih, aspek kesehatan menjadi kunci dari penyebaran yang memakan korban jiwa dengan jumlah yang tidak sedikit.

Akibat pandemi ini memberi dampak pada beredarnya berbagai informasi yang beredar tanpa kendali. Tak pelak hoakspun menjadi bagian yang tidak terpisahkan, bahkan makin meningkat jumlahnya. Banyak oknum dan pihak-pihak tidak bertanggungjawab dengan sengaja menyebarkan informasi yang tidak benar, dan bahkan hingga menyesatkan masyarakat.

Selain pandemi yang menyebabkan hoaks dari berbagai sektor, ditambah pada tahun 2020 ini berbarengan di selenggarakan pemilukada serentak di berbagai kabupaten/ kota di Indonesia. Ada 270 daerah terdiri 9 provinsi, 224 kabupaten, dan 37 kota telah siap melakukan pesta demokrasi.

Selain itu beberapa data menyebutkan bahwa Perkembangan mengenai infodemik hingga tahun 2020 ini meningkat sangat signifikan. Mafindo dalam hasil risetnya menyatakan bahwa sektor agama dan politik menduduki rangking 
2 besar. Tak heran menduduki peringkat tinggi dengan 55\%, agama $8,4 \%$, kesehatan $7 \%$, kriminalitas $5,8 \%$ dan bencana $2 \%$, sisanya tema umum $21,8 \%$.

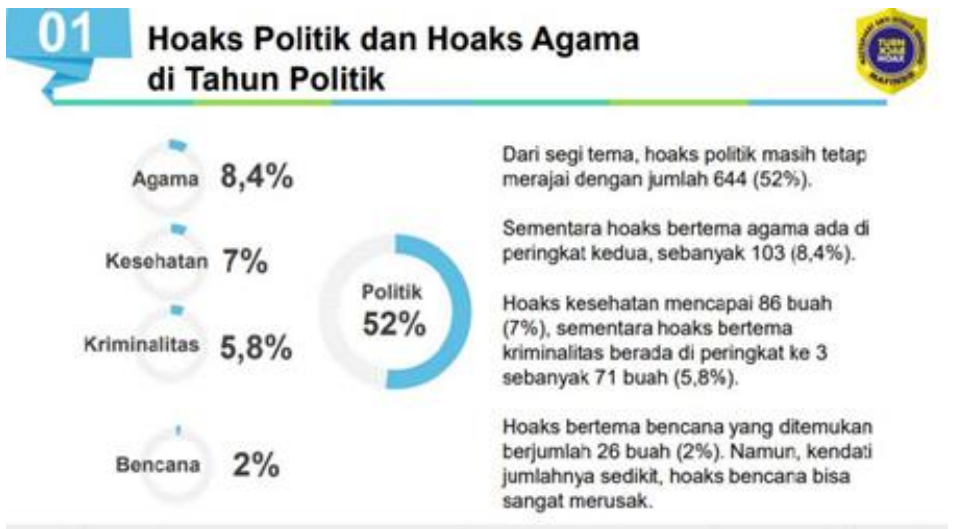

Sumber (Mafindo,2020)

Berbagai peristiwa dan isu-isu hoaks terjadi dan tumbuh dengan subur. Dan hal itu banyak digunakan untuk melakukan serangkaian kampanye hitam untuk menyerang lawan politiknya. Ini menjadi sebuah preseden buruk tidak hanya dalam tataran demokrasi, tetapi justru memanfaatkan beberapa momentum seperti pandemi dan pilkada serentak menjadi sarana bagi penyebar hoaks untuk menggelar aksinya.

Melihat fenomena tersebut, maka ingin diketahui beberapa masalah yang harus dipecahkan. Diantaranya adalah :

1. Bagaimana hoak ini berkembang dalam media sosial masa kini?

2. Bagaimana hoak dapat mempengaruhi kehidupan masyarakat?

3. Bagaimana perilaku masyarakat dalam menerima informasi hoak? 


\section{BAB III TUJUAN PENELITIAN}

Tujuan penelitian ini adalah :

1. Untuk mengetahui bagaimana hoak dapat mempengaruhi kehidupan masyarakat

2. Untuk mengetahui bagaimana hoak berkembang dalam media sosial

3. Bagaimana bagaimana perilaku masyarakat dalam menerima informasi hoak? 


\section{BAB IV \\ METODOLOGI PEMECAHAN MASALAH}

Penelitian ini menggunakan pendekatan kualitatif yang bertujuan untuk menentukan dan mencari, mengumpulkan, mengolah dan menganalisis data hasil penelitian. Penelitian kualitatif atau qualitative research adalah suatu penelitian yang ditujukan untuk mendeskripsikan dan menganalisis fenomena, peristiwa, aktifitas social, sikap, kepercayaan, persepsi, pemikiran orang secara individual maupun kelompok. Beberapa deskripsi digunakan untuk menemukan prinsip-prinsip dan menjelaskan yang mengarah pada penyimpulan.

Penelitian kualitatif adalah penelitian field research jenis penelitian lapangan.penelitian dengan menghasilkan data deskriptif berupa kata-kata tertulis atau lisan dari orang-orang dan perilaku yang dapat diamati. Metode deskriptif adalah sebuah metode atau prosedur pemecahan masalah yang diselidiki dengan menggambarkan atau melukiskan keadaan subyek atau objek penelitian. Dapat melalui seseorang, lembaga, atau masyarakat, dan lain-lain).dalam sebuah proses yang sedang berlangsung, didasari oleh fakta-fakta yang ada. (Sugiono,2007).

Sementara itu, pendapat lain mengatakan bahwa penelitian kualitatif merupakan suatu penelitian yang bertujuan yang ditujukan untuk mendeskripsikan dan menganalisis fenomena, peristiwa, aktivitas sosial, sikap, kepercayaan, persepsi, pemikiran orang secara individual maupun kelompok. Sukmadinata mengatakan, penelitian ini memiliki sifat induktif, peneliti membiarkan permasalahan-permasalahan muncul dari data atau dibiarkan terbuka untuk interpretasi. Kemudian, data dihimpun dengan pengamatan yang seksama, mencakup deskripsi dalam konteks yang mendetail disertai catatan-catatan hasil wawancara 
yang mendalam, serta hasil analisis dokumen dan catatan- catatan. (Sukmadinata,2011)

Penelitian kualitatif mempunyai dua tujuan utama, yang pertama yaitu, menggambarkan dan mengungkap ( to describe and explore) dan kedua menggambarkan dan menjelaskan (to describe and explaim).(Moleong,2012).

Penelitian ini menyoroti berbagai fenomena kasus hoax yang sedang ramai di masyarakat. Sesuai pendapat Bogdan\&Taylor bahwa Penelitian kualitatif adalah upaya yang dilakukan dengan jalan bekerja dengan data, mengorganisasikan data, memilah-milahnya menjadi satuan yang dapat dikelola, mensintesiskannya, mencari dan menemukan pola, menemukan apa yang penting dan apa yang dipelajari, dan memutuskan apa yang dapat diceriterakan kepada orang lain. Selanjutnya, disebutkan bahwa, berdasarkan definisi di atas dapat disimpulkan bahwa langkah awal dari analisis data adalah mengumpulkan data yang ada, menyusun secara lengkap, mengelola serta menganalisis (Moleong, 2007).

Metode analisis yang digunakan adalah analisis isi (content analysis). Metode penelitian bersifat membahas secara mendalam terhadap isi suatu informasi tertulis atau tercetak dalam media massa. Analisis isi dapat digunakan untuk menganalisis semua bentuk komunikasi. Baik surat kabar, berita radio, iklan televisi maupun semua bahan-bahan dokumentasi yang lain, termasuk konten media sosial. Termasuk di dalamnya adalah bagaimana melakukan analisis terhadap konten berita dari sebuah media online tertentu. Pemberitaan media online juga memiliki urgensi terhadap idiologi sebuah media dalam melakukan framing berita. Termasuk dalam memberitakan suatu isu-isu tertentu yang lagi hangat dibicarakan masyarakat. (Triyono,2020) 
Menurut Bungin, mengatakan analisis isi memiliki tujuan ;

Pertama ; Menggambarkan Karakteristik Pesan. Analisis isi ini banyak dipakai untuk menggambarkan karakteristik isi dari suatu pesan. Ada empat desain analisis isi yang umumnya dipakai untuk menggambarkan karakteristik pesan yaitu a) Analisis yang dipakai untuk menggambarkan pesan dari sumber yang sama tetapi dalam waktu yang berbeda b)Analisis isi dipakai untuk melihat pesan pada situasi yang berbeda, situasi disini dapat berupa konteks yang berbeda, sosial dan politik. c)Analisis isi dipakai untuk melihat pesan pada khalayak yang berbeda, khalayak disini merujuk pada pembaca, pendengar atau pemisa media yang berbeda.d)Analisis isi dipakai untuk melihat pesan dari komunikator yang berbeda.

Kedua, Menarik Kesimpulan Penyebab Dari Suatu Pesan. Analisis isi tidak hanya dapat dipakai untuk melihat gambaran suatu pesan. Analisis isi juga dapat digunakan untuk menarik kesimpulan penyebab dari suatu pesan. Dalam analisis isi yang menjadi fokus disini tidak deskripsi dari pesan, tetapi menjawab pertanyaan mengapa pesan isi muncul dalam bentuk tertentu.

Dalam pesan-pesan analisis isi media kualitatif lebih banyak dipakai untuk meneliti dokumen yang dapat berupa teks, gambar, simbol, dan sebagainya untuk memahami budaya dari suatu konteks sosial tertentu. Dokumen dalam analisis isi kualitatif ini merupakan metode analisis yang integratif dan lebih secara konseptual untuk menemukan, mengidentifikasi, mengolah dan menganalisa dokumen untuk memahami makna, signifikansi dan relevansinya.

Tujuan lain dari penelitian analisis isi kualitatif ini sebenarnya adalah sistematis dan analitis, tetapi tidak kaku (rigid) seperti analisis isi kuantitatif. Analisis isi yang sifatnya kualitatif tidak hanya mampu mengidentifikasi pesan-pesan manifest, melainkan juga latent messages dari sebuah dokumen yang diteliti. 
Jadi, lebih mampu melihat kecenderungan isi media berdasarkan context (situasi yang sosial di seputar dokumen atau teks yang diteliti), process (bagaimana suatu proses produksi media/isi pesannya dikreasi secara actual dan diorganisasikan secara bersama) dan emergence (pembentukan secara gradual/bertahap dari makna sebuah pesan melalui pemahaman dan intepretasi) dari dokumen-dokumen yang diteliti (Bungin, $2004:$ 144-147).

Pada analisis isi kualitatif ini memfokuskan riset isi komunikasi yang tersurat (tampak atau manifest) media sosial dan laman internet. Karena itu tidak dapat digunakan untuk mengetahui isi komunikasi yang tersirat (latent), sehingga diperlukan suatu analisis isi yang lebih mendalam dan detail untuk memahami produk isi media dan mampu menghubungkanya dengan konteks sosial/realitas yang terjadi sewaktu pesan dibuat. Semua pesan dalam teks, simbol,gambar adalah produk sosial dan budaya masyarakat. Oleh karenanya hal itu di sebut analisis isi kualitatif.

Analisis isi kualitatif disebut pula sebagai Ethnographic Content Analysis (ECA), yaitu perpaduan analisis isi objektif dengan observasi partisipan. (Altheide,1996:2) Artinya, istilah ECA adalah periset berinteraksi dengan material-material dokumentasi atau bahkan melakukan wawancara mendalam sehingga pertanyaan-pertanyaan yang spesifik dapat diletakkan pada konteks yang tepat untuk di analisis.

Beberapa yang harus diperhatikan oleh periset antara lain : Isi (content) atau situasi sosial seputar dokumen (pesan/teks) yang diriset. Contohnya, periset harus memahami faktor ideologi media, background para jurnalis \& bisnis. Faktor-faktor ini juga akan menentukan isi berita dari media tersebut.

Proses atau bagaimana suatu produk media/isi pesannya dikreasi secara aktual dan diorganisasikan secara bersama. 
Emergence, yaitu pembentukan secara gradual / bertahap dari makna sebuah pesan melalui pemahaman dan interprestasi. Periset menggunakan dokumen atau teks untuk membantu memahami proses dan makna dari aktivitas-aktivitas sosial. Periset akan mengetahui apa dan bagaimana pembuat pesan di pengaruhi oleh lingkungan sosialnya atau bagaimana pembuat pesan mendefinisikan sebuah situasi.

Teknik pengumpulan data pada kesempatan ini adalah bersumber dari konten-konten di media sosial yang sedang menjadi perbincangan publik. Diantaranya melalui media sosial instagram, facebook dan twitter yang telah diverifikasi oleh kominfo melalui laman kominfo,go,id, melalui Masyarakat Anti Fitnah Indonesia (Mafindo) dalam kanal www.cekfakta.com, www.turnbackhoax.id, chatboat Mafindo. Setelah data dikumpulkan, kemudian dianalisis berdasar konten secara deskriptif. 


\section{BAB V \\ TEORI \& TINJAUAN PUSTAKA}

\section{A. Paradigma}

Dalam penelitian ini penulis menggunakan paradigma kritis. Paradigma ini adalah pengetahuan yang selalu mencurigai adanya kepentingan dibalik sesuatu. Maksud paradigma ini adalah, mengkritik ketidakadilan sistem dominan (kapitalisme), melainkan berusaha mengubah sistem dan struktur tersebut agar menjadi lebih adil. Pradigma ini meletakkan epistemologi kritik Marxisme dalam seluruh metodologi penelitiannya. Paradigma ini adalah merupakan salah satu aliran dalam ilmu sosial yang berbasis pada ide-ide Karlmarx dan Engels (dalam Denzin \& Lincoln [eds.],2010). Paradigma ini juga digolongkan sebagai penelitian subyektif.

Istilah teori kritis pertama kali ditemukan Max Hokheimer pada tahun 30-an. Awalnya teori kritis berarti pemaknaan kembali gagasan-gagasan ideal modernitas berkaitan dengan nalar dan kebebasan. Pemaknaan ini dilakukan dengan mengungkap deviasi dari gagasan-gagasan ideal tersebut dalam bentuk saintisme, kapitalisme, industri kebudayaan, dan institusi politik borjuis. Untuk memahami, pendekatan teori kritis, harus menempatkannya dalam konteks Idealisme Jerman dan kelanjutannya. Karl Marx dan generasinya menganggap Hegel sebagai orang terakhir dalam tradisi besar pemikiran filosofis yang mampu mengamankan pengetahuan tentang manusia dan sejarah.

Namun, karena beberapa hal, pemikiran Marx mampu menggantikan filsafat teoritis Hegel. Menurut Marx, hal ini terjadi karena Marx menjadikan filsafat sebagai sesuatu yang praktis; yakni menjadikannya sebagai cara berpikir (kerangka pikir) masyarakat dalam mewujudkan idealitasnya. Dengan 
menjadikan nalar sebagai sesuatu yang sosial dan menyejarah, skeptisisme historis akan muncul untuk merelatifkan klaimklaim filosofis tentang norma dan nalar menjadi ragam sejarah dan budaya forma-forma kehidupan.

Pemikiran ini menyatakan bahwa teori kritis menolak skeptisisme dengan tetap mengaitkan antara nalar dan kehidupan sosial. Dengan demikian, teori kritis menghubungkan ilmu-ilmu sosial yang bersifat empiris dan interpretatif dengan klaim-klaim normatif tentang kebenaran, moralitas, dan keadilan yang secara tradisional merupakan bahasan filsafat. Dengan tetap memertahankan penekanan terhadap normativitas dalam tradisi filsafat, teori kritis mendasarkan cara bacanya dalam konteks jenis penelitian sosial empiris tertentu, yang digunakan untuk memahami klaim normatif itu dalam konteks kekinian.

Pada masa modern, filsafat secara dibedakan dari bidang sains. Disebutkan oleh Locke bahwa filsafat sebagai pekerja kasar. Namun bagi Kant, filsafat memiliki dua peran, diantaranya adalah :

Pertama, sebagai "hakim" yang dengannya sains dinilai. Kedua, sebagai wilayah untuk memunculkan pertanyaan normatif. Untuk menjawab pertanyaan-pertanyaan normatif, dalam perspektif Kantian, sains tidak dibutuhkan, karena hal itu dijawab melalui analisis transenden. Teori kritis berorientasi emansipasi berusaha mengkontekstualisasi klaim-klaim filosofis tentang kebenaran dan universalitas moral tanpa mereduksinya menjadi sekedar kondisi sosial yang menyejarah. Teori kritis berusaha menghindari hilangnya kebenaran yang telah dicapai oleh pengetahuan masa lalu. Tentang hal ini Horkheimer menyatakan bahwa semua pemikiran, benar atau salah, tergantung pada keadaan yang berubah sama sekali tidak berpengaruh pada validitas sains. 
Teori kritis memungkinkan kita membaca produksi budaya dan komunikasi dalam perspektif yang luas dan beragam. Ini bertujuan, untuk melakukan eksplorasi refleksif terhadap pengalaman yang kita alami dan cara kita mendefinisikan diri sendiri, budaya kita, dan dunia. Saat ini teori kritis menjadi salah satu alat epistemologis yang dibutuhkan dalam studi humaniora.

Hal ini didorong oleh kesadaran bahwa makna bukanlah sesuatu yang alamiah dan langsung. Bahasa bukanlah media transparan yang dapat menyampaikan ide-ide tanpa distorsi, sebaliknya ia adalah seperangkat kesepakatan yang berpengaruh dan menentukan jenis-jenis ide dan pengalaman manusia. Dengan berusaha memahami proses dimana teks, objek, dan manusia diasosiasikan dengan makna-makna tertentu, teori kritis memertanyakan legitimasi anggapan umum tentang pengalaman, pengetahuan, dan kebenaran.

Dalam interaksi keseharian dengan orang lain,alam, dalam kepala seseorang selalu menyimpan seperangkat kepercayaan dan asumsi yang terbentuk dari pengalaman. Dalam arti luas berpengaruh pada cara pandang seseorang, yang sering tidak tampak. Teori kritis berusaha mengungkap dan memertanyakan asumsi dan praduga itu.

Dalam usahanya, teori kritis menggunakan ide-ide dari bidang lain untuk memahami pola-pola dimana teks dan cara baca berinteraksi dengan dunia. Hal ini mendorong munculnya model pembacaan baru. Karenanya, salah satu ciri khas teori kritis adalah pembacaan kritis dari dari berbagai segi dan luas. Teori kritis adalah perangkat nalar yang, jika diposisikan dengan tepat dalam sejarah, mampu merubah dunia.

Pendekatan teori kritis tidak bersifat kontemplatif atau spektulatif murni. Teori Kritis pada titik tertentu memandang dirinya sebagai pewaris ajaran Karl Marx, sebagai teori yang 
menjadi emansipatoris. Teori Kritis tidak hanya mau menjelaskan, mempertimbangkan, merefleksikan dan menata realitas sosial tapi juga bahwa teori tersebut mau mengubah. Pada dasarnya, teori kritis mau menjadi praktis. Teori Kritis tidak mau mengikuti jejak Karl Marx. Kelemahan marxisme pada umumnya adalah mereka menjiplak analisa Marx dan menerapkannya mentah- mentah pada masyarakat modern.

Oleh sebab itu,biasanya marxisme justru lebih terkesan dogmatis daripada ilmiah. Teori Kritis mengadakan analisa baru terhadap masyarakat yang dipahami sebagai masyarakat kapitalis lanjut. Yang direkonseptualisasi dalam pemikiran teori kritis adalah maksud dasar teori Karl Marx, yaitu pembebasan manusia dari segala belenggu peng-hisapan dan penindasan. Pembebasan manusia dari segala belenggu penghisapan dan penindasan berangkat dari konsep kritik.

Konsep kritik sendiri yang diambil oleh Teori Kritis berangkat dari 4 (empat sumber) kritik yang di konseptualisasikan oleh. Immanuel Kant, Hegel, Karl Marx dan Sigmund Freud.

Kritik dalam pengertian pemikiran Kantian adalah kritik sebagai kegiatan penguji kesahihan klaim pengetahuan tanpa prasangka. Kritik dalam pengertian Hegel didefinisikan sebagai Refleksi diri atas tekanan dan kontradiksi yang menghambat proses pembentukan diri-rasio dalam sejarah manusia. Kritik dalam pengertian Marxian berarti usaha untuk mengemansipasi diri dari alienasi atau keterasingan yang dihasilkan oeh hubungan kekuasaan dalam masyarakat. Kritik dalam pengertian Freudian adalah refleksi atas konflik psikis yang menghasilkan represi dan memanipulasi kesadaran. Adopsi Teori Kritis atas pemikiran Freudian yang sangat psikologistik dianggap sebagai pengkhianatan terhadap ortodoksi marxisme klasik. (Soeryanto,2015). 


\section{Paradigma Kritis Dan Media}

Penelitian media massa lebih diletakkan dalam kesadaran bahwa teks atau wacana dalam media massa mempunyai pengaruh yang sedemikian rupa pada manusia (Littlejohn, 2002: 163-183). Seluruh aktivitas dan pemaknaan simbolik dapat dilakukan dalam teks media massa. Pada dasarnya teks media massa bukan realitas yang bebas nilai. Pada titik kesadaran pokok manusia, teks selalu memuat kepentingan. Teks pada prinsipnya telah diambil sebagai realitas yang memihak. Tentu saja teks dimanfaatkan untuk memenangkan pertarungan idea, kepentingan atau ideologi tertentu kelas tertentu. Pada titik tertentu, teks media pada dirinya sudah bersifat ideologis (Littlejohn, 2002:217).

Pembahasan yang harus disadari adalah bukan hanya terletak bahwa teks media selalu bersifat ideologis tapi terutama adalah kemampuan untuk membedakan antara kuasa teks itu sendiri dengan kuasa struktur makro yang secara sengaja atau tidak sengaja merekonstruksi, merepresentasikan dan memaknai teks tersebut (Shoemaker \& Reese, 1991: 53-205). Dalam arti bahwa, meski konsumen dan produsen teks media punya opsi bagaimana teks harus disimbolisasikan dan dimaknai tetap saja ada bingkai aktivitas dan opsi mereka yang terbentuk dan dipengaruhi oleh faktor yang berada di luar jangkauan kendali sadar konsumen atau produsen teks media.

Pengenalan dan pemahaman yang cukup komprehensif atas struktur sistem produksi media, rasionalitas dan ideologi yang berada di balik teks media yang bersangkutan menjadi hal yang penting. Diperlukan paradigma penelitian dan metode penelitian yang mampu menelanjangi, menggali dan mengeksplorasi struktur, rasionalitas dan ideologi yang kesemuanya bersifat laten termuat dalam sebuah teks media (Dedy N. Hidayat, 2000: 127-164). 


\section{Asumsi dasar paradigma kritis}

Asumsi dasar dalam paradigma kritis ini adalah keyakinan bahwa ada kekuatan laten dalam masyarakat yang begitu berkuasa mengontrol proses komunikasi masyarakat. Ini berarti paradigma kritis melihat adanya realitas di balik kontrol komunikasi masyarakat.

Masalahnya siapa yang mempunyai kekuatan kontrol tersebut? Mengapa mengontrol ? Ada kepentingan apa ? Dengan beberapa kalimat pertanyaan itu, terlihat bahwa teori kritis melihat adanya proses dominasi dan marginalisasi kelompok tertentu dalam seluruh proses komunikasi masyarakat. Hal ini menyatakan bahwa proses penyebaran dan aktivitas komunikasi massa juga sangat dipengaruhi oleh struktur ekonomi politik masyarakat yang bersangkutan. Proses pemberitaan tidak bisa dipisahkan dengan proses politik yang berlangsung dan akumulasi modal yang dimanfaatkan sebagai sumber daya. Ini merupakan proses interplay, di mana proses ekonomi politik dalam media akan membentuk dan dibentuk melalui proses produksi, distribusi dan konsumsi media itu. Ini berarti bahwa apa yang terlihat pada permukaan realitas belum tentu menjawab masalah yang ada. Apa yang nampak dari permukaan harian belum tentu mewakili kebenaran realitas itu sendiri. Teori kritis pada akhirnya selalu mengajarkan kecurigaan dan cenderung selalu mempertanyakan realitas yang ditemui, termasuk di dalamnya teks media itu sendiri.

Paradigma kritis tidak cukup puas pada jawaban, pola, struktur, simbol dan makna yang tersedia. Perlu ada pemaknaan yang lebih komprehensif dan kritis atas media yang ada. Beberapa keyakinan teori kritis menjadi acuan awal pemahaman kita terhadap studi teks media dalam konteks paradigma kritis. 
Teori kritis melihat bahwa media tidak lepas kepentingan, terutama sarat kepentingan kaum pemilik modal, negara atau kelompok yang menindas lainnya. Dalam artian ini, media menjadi alat dominasi dan hegemoni masyarakat. Konsekuensi logisnya adalah realitas yang dihasilkan oleh media bersifat pada dirinya bias atau terdistorsi.

Teori ini menyoroti bahwa pembentuk kesadaran. Representasi yang dilakukan oleh media dalam sebuah struktur masyarakat lebih dipahami sebagai media yang mampu memberikan konteks pengaruh kesadaran (manufactured consent). Dengan demikian, media menyediakan pengaruh untuk mereproduksi dan mendefinisikan status atau memapankan keabsahan struktur tertentu. Inilah sebabnya, media dalam kapasitasnya sebagai agen sosial sering mengandaikan juga praksis sosial dan politik.

Pengartian \& reproduksi realitas yang dihasilkan dari media massa tidak hanya dilihat sebagai akumulasi fakta atau realitas itu sendiri. Reproduksi realitas melalui media merupakan representasi tarik ulur ideologi atau sistem nilai yang mempunyai kepentingan yang berbeda satu sama lain.

Dalam hal ini, media tidak hanya memainkan perannya hanya sekedar instrumen pasif dan tidak dinamis dalam proses rekonstruksi budaya tapi media massa tetap menjadi realitas sosial yang dinamis.

Pertama, reproduksi realitas dalam media pada dasarnya dan umumnya akan sangat dipengaruhi oleh bahasa (Littlejohn, 2002:210-211), simbolisasi pemaknaan dan politik penandaan. Bahasa di samping sebagai realitas sosial, tetap bisa dilihat sebagai sebuah sistem penandaan. Sistem penandaan dalam arti bahwa bahasa atau suatu 
realitas yang ingin menandakan realitas lainnya (peristiwa atau pengalaman hidup manusia). Dengan demikian, sebuah realitas dapat ditandakan secara berbeda pada peristiwa yang sama. Atau, dapat dikatakan bahwa pemaknaan yang tidak sama bisa dilekatkan kepda peristiwa yang sama. Masalah terjadi ketika suatu makna yang ditafsirkan dan dikonstruksi ulang oleh kelompok tertentu dari peristiwa yang sama tersebut cenderung mendominasi penafsiran. Bagaimana mungkin sebuah makna tertentu bisa lebih unggul dan lebih diterima dibandingkan pemaknaan lainnya ? Mengapa pemaknaan lain di luar pemaknaan yang sudah ditentukan justru dimarginalisasikan? Dengan kata lain, bahwa sesungguhnya ketika kita melihat proses bahasa dan pemaknaan, sebetulnya kita juga melihat ranah atau wilayah pertarungan sosial (Stuart Hall, 1982:80). Pertarungan sosial tersebut lebih konkret terbentuk dalam sebuah wacana serta terartikulasikan dalam proses pembentukan dan praksis bahasa.

Kedua, bahasa dalam konteks wacana - terutama dalam konteks wacana komunikasi - sebetulnya mencakup pengiriman pesan dari sistem syaraf satu orang kepada yang lain, dengan maksud untuk menghasilkan sebuah makna sama dengan yang ada dalam benak si pengirim (Tubs \& Moss, 1994: 66). Pesan verbal selalu memakai kata. Kata selalu merujuk pada keberadaan sebuah bahasa. Ini berarti kita sepakat bahwa kita menggunakan simbol bahasa dalam aktivitas komunikasi.

Dalam perkembangan ilmu komunikasi modern, bahasa adalah kombinasi kata yang diatur dan dikelola secara sistematis dan logis sehingga bisa dimanfaatkan sebagai alat komunikasi. Artinya, kata merupakan bagian integral dari keseluruhan simbol yang dibuat oleh suatu kelompok tertentu. Kata selalu bersifat simbolik, simbol 
dapat diartikan sebagai realitas yang mewakili atau merepresentasikan idea, pikiran, gagasan, perasaan, benda atau tindakan manusia yang dilakukan secara arbitrer, konvensional dan representatifintrepretif.

Oleh sebab itu, tidak ada hubungan yang berlaku secara alamiah dan selalu bersifat koresponden antara simbol dengan realitas yang disimbolkan. Ketiga, politik penandaan lebih banyak bermakna pada soal bagaimana praksis sosial pembentukan makna, kontrol dan penentuan suatu makna tertentu. Peran media massa dalam praksis sosial penentuan tanda dan makna tidak melepaskan diri dari proses kompetisi ideologi. Relasi dominasi dan kompetisi ideologis tidak hanya berproses pada tataran aparatur kelompok dominan saja tapi juga melalui produksi dan reproduksi kekuasaan yang berada dalam ruang budaya - tempat di mana makna hidup disusun.

Produksi konstruksi realitas, menghubungkan dimensi politik wacana dengan dimensi politik ruang. Hal ini disebabkan bahwa hanya dalam ruang tertentu saja praksis wacana yang lahir dari sejarah dominasi dan kompetisi kultur yang panjang hingga dimenangkannya kompetisi oleh kekuatan paling dominan dan hegemonis yang pada gilirannya menentukan rekayasa politik wacana.

\section{Dimensi dalam paradigma kritis}

Merupakan identifikasiperbedaan antara paradigma klasik, kritis, dan konstruktivis, berdasarkan empat elemen yang dimiliki setiap paradigma (epistemologi, ontologi, metodologi, dan aksiologi), dan merupakan rangkuman atau penyimpulan darisejumlah kepustakaan (a.i., Guba, 1994; Denzin and Lincoln, 1994). 
Pada dimensi Ontologis, Realitas yang teramati merupakan realitas "semu" (virtual reality) yang telah terbentuk oleh proses sejarah dankekuatan-kekuatan sosial, budaya, dan ekonomi-politik (Historical realism).

Dimensi Epistomologis, menjelaskan Hubungan peneliti dengan yang diteliti selalu dijembatani nilai-nilai tertentu. Pemahaman tentang suatu realitas merupakan value mediated findings, (Transactionalist) subjectivist).

Dimensi Aksiologis, dijelaskan, bahwa nilai, etika dan pilihan moral merupakan bagian tak terpisahkan dari penelitian. Peneliti menempatkan diri sebagai transformativein-tellectual, advokat dan aktivis. Tujuan penelitian: kritik sosial,transformasi, emansipasidan social em-powerment. (Activist).

Sementara, paradigma yang digunakan adalah paradigma kritis. Paradigma kritis menurut McQuail memiliki beberapa asumsi yang penting. Pertama, memandang itu masyarakat bersifat kritis dan menolak netralitas nilai dalam penelitian. Kedua, menolak model tansmisi komumkasi linear yang mengabaikan sikap aktif khalayak. Ketiga, memandang pesan dan teknologi media sebagai faktor yang non deterministik. Keempat, paradigma kritis mengadopsi perspektif intepretatif dalam memandang realitas sosial. Kelima, menggunakan metoda kualitatif dalam memproses data. Keenam, memilih teori kultural atau teori ekonomi-politik. Ketujuh, sangat peduli terhadap ketidakadilan dan ketidakseimbangan sosial serta melakukan oposisi di tengah masyarakat.

Melalui metodologi tersebut tersebut penulis memberikan solusi pemecahan dengan menerapkan teknik komunikasi efektif, berpikir kritis dan pola 3,8 yakni 3 level 
dan 8 kompetensi unggulan. Komunikasi efektif dilakukan berdasar formula Laswell (Who says what in with channel to whom with what effect). Berikutnya melalui pemahanan Berpikir Kritis yang meliputi rasional, obyektif dan mempertimbangkan resiko, dan pola 3, 8 ; terdiri dari 3 level (Tahu, Tanggap, Tangguh), 8 Kompetensi (mengakses informasi, mengelola informasi, mendesain pesan, memproses informasi, berbagi pesan, membangun ketangguhan diri, perlindungan data, Kolaborasi.

\section{B. Teori}

Beberapa penelitian telah banyak dilakukan, salah satunya oleh Christiany Juditha tahun 2018 dengan judul "Hoax Communication Interactivity in Social Media and Anticipation" (Interaksi Komunikasi Hoax di Media Sosial serta Antisipasinya). Dalam riset ini, menyoroti fenomena hoax di Indonesia. Adanya banyak informasi yang menimbulkan keraguan dan sering membingungkan masyarakat. Hal ini juga banyak dimanfaatkan pihak yang tidak bertanggung jawab untuk menanamkan fitnah dan kebencian. Metode penelitian yang digunakan yaitu pendekatan kualitatif dengan menganalisis tiga kasus hoax yang ramai di masyarakat menyangkut pemerintahan Jokowi dan Gubernur DKI Jakarta, Ahok. Penelitian ini menyimpulkan bahwa interaksi komunikasi terbangun dengan sangat dinamis. Pengirim atau penerima pesan hoax merupakan pihak yang tidak menyenangi pemerintah. Penerima pesan lainnya juga pihak yang tidak sepakat dan membantah hoax sebagai dukungan terhadap pemerintah. Motif politik sangat kental dalam kasus ini dan ada tujuan menjatuhkan pemerintah yang sedang berkuasa atau mencegah Ahok menjadi gubernur DKI Jakarta lagi. Hoax yang banyak disebar berulang-ulang melalui media sosial dapat membentuk opini publik bahwa berita tersebut benar adanya. Ada tiga pendekatan penting untuk mengantisipasi penyebaran hoax di masyarakat yaitu pendekatan kelembagaan, teknologi dan literasi. 
Penelitian kedua dilakukan oleh Aminah dan Novita Sari tahun 2019 dengan judul "Dampak Hoax Di Media Sosial Facebook Terhadap Pemilih Pemula". Media sosial Facebook merupakan salah satu media yang sangat berpengaruh dalam kehidupan masyarakat saat ini. Melalui media tersebut, penyebaran informasi dapat dengan cepat tersampaikan pada masyarakat khususnya kepada para pengguna Facebook. Hal ini menimbulkan rasa kekhawatiran dari pengguna dalam menyaring informasi untuk menghindari berita-berita hoax. Penelitian ini bertujuan untuk mengkaji dampak berita bohong (hoax) pada media social Facebook terhadap pemilih pemula menjelang Pilpres dan Pileg di Kecamatan Panga Kabupaten Aceh Jaya. Metode penelitian ini, menggunakan metode kualitatif deskriptif. Data yang diperlukan dalam penulisan ini diperoleh melalui penelitian lapangan dengan cara mewawancarai sembilan orang informan. Hasil penelitian menunjukkan bahwa media Facebook sering kali digunakan oleh para pemilih pemula untuk mendapatkan informasiinformasi terkait Pemilu. Namun, banyaknya berita hoax yang beredar membawa pengaruh kepada para pemilih pemula. Adapun dampak berita bohong terhadap pemilih pemula yaitu sulit membedakan berita hoax dan asli, mudah terprovokasi, mudah membenci dan perubahan pilihan/ dukungan.

Penelitian ketiga dilakukan Muhammad Edy Susilo tahun 2020 dengan judul "Perbandingan Pola Penyebaran Hoaks Antar generasi". Penelitian ini menyoroti pola penyebaran hoaks antara generasi $X$ dan Generasi Z. Penelitian ini menggunakan Teori Generasi dari McPrenski dan konsep DeFleur dan Ball-Rokeach mengenai Teori Kategori Sosial. Metodenya adalah survei di Kabupaten Sleman Yogyakarta dengan sample size 240. Penelitian diadakan menjelang Pemilihan Umum Indonesia 2019, di mana terjadi penyebaran hoaks yang tinggi. Uji hipotesis dilakukan dengan menggunakan T-test. Hasil penelitian menunjukkan bahwa terdapat perbedaan pola penyebaran hoaks di antara kedua 
generasi. Generasi $X$ tampak lebih aktif dalam menyebarkan hoaks dibandingkan dengan Generasi Z. Temuan ini semakin menegaskan Teori Generasi dan terminologi digital immigrant dan digital native. Temuan penelitian memberikan harapan positif karena Generasi $Z$ yang akan lebih aktif di masa depan tampak kurang tertarik dengan hoaks dan cenderung lebih melek secara digital. Gerakan digital literacy sebaiknya lebih mempertimbangkan kekhasan masing-masing kelompok sasaran karena di mereka memiliki karakteristik yang berbeda.

Sementara penelitian yang dilakukan penulis kali ini adalah teori yang digunakan adalah Hermeneutika Paul Ricoeur Dalam Memandang Hoax. Paul Ricoeur adalah salah satu tokoh hermenutika yang memiliki beberapa teori tentang memahami sebuah teks berdasarkan kejadian, wacana (lisan), dan teks. Dalam memahami dan mengidentifikasi hoax, ada beberapa teori milik Ricoeur yang digunakan gunakan dalam tulisan ini, yaiknu teori fiksasi. Berikut penerapan teori hermeneutika Riroeur dalam penerapannya terhadap hoax masa kini.

\section{Teori Fiksasi}

Salah satu teori hermeneutika Ricoeur yaitu,teori fiksasi ini menjelaskan bagaimana menyampaikan dan memahami proses dari wacana lisan dibentuk ke dalam sebuah teks tulis, atau dari lisan ke penulisan. Menurut Ricoeur, jika makna teks mau diungkap atau dipahami, seorang penafsir akan menghadapi dua alternatif, yaitu jalan langsung yang ditempuh oleh Heiddeger yang kemudian diikuti oleh Gadamer atau jalan melingkar yang ditempuh oleh Husserl. Jika menggunakan jalan langsung, seorang penafsir mehamai teks secara langsung tanpa menggunakan metodologi untuk memahami dan menyelidiki makna yang terkandung dalam teks. 
Dengan jalan ini, banyak pengguna media sosial ketika menerima berita simpang siur akan langsung mempercayai tanpa menyelidiki kebenaran faktual sesuai kejadian yang seungguhnya. Lalu dengan jalan melingkar atau yang sebenarnya disebut dengan fenomenologi Husserl. Cara ini membuat penafsir atau pembaca lebih dulu menyelidiki kebenaran dari makna di balik teks. Ricoeur menempuh jalan melingkar itu untuk menyingkap makna tersembunyi di dalam teks.

Dengan menggunakan jalan melingkar atau fenomenologi ini, seorang pengguna dan pembaca berita di media sosial akan mempertimbangkan berita yang mereka baca dengan menyelidiki fenomena kebenaran yang terkandung dalam teks/berita. Cara ini lebih aman dan mendalam dalam membaca sebuah berita agar terhindar dari hoax, dengan begitu seorang pembaca akan lebih nyaman dan aman dalam membaca berita. Dalam dunia digital seperti saat ini hanya segelintir orang yang menggunakan cara seperti ini karena sudah banyak beritaberita yang tidak benar namun seolah sesuai dengan keadaan yang sesungguhnya.

\section{Teori Kritis, Paradigma dan Wacana Media}

Menurut Hidayat Ilmu komunikasi dapat dikategorikan dalam ilmu pengetahuan yang mempunyai aktivitas penelitian yang bersifat multi paradigma. Ini berarti, ilmu komunikasi merupakan bidang ilmu yang menampilkan sejumlah paradigma atau perspektif dasar pada waktu bersamaan (Hidayat, 1999:431-446).

Paradigma sendiri, dapat didefinisikan sebagai: " $a$ set of basic beliefs (or metaphysics) that deals with ultimates or first principles... a world view that defines, for its holder, the nature of the 'world'..."(Guba, dalam Denzin \& Lincoln, 1994:107). Paradigma merupakan, orientasi dasar untuk teori dan riset. Pada umumnya suatu paradigma keilmuan merupakan sistem 
keseluruhan dari berfikir, selanjutnya, paradigma terdiri dari asumsi dasar, teknik riset yang digunakan, dan contoh seperti apa seharusnya teknik riset yang baik (Newman, 1997:62-63).

Paradigma kritis,pada dasarnya adalah paradigma ilmu pengetahuan yang meletakkan epistemologi kritik Marxisme dalam seluruh metodologi penelitiannya. Fakta memberi kenyataan bahwa paradigma kritis yang diinspirasikan dari teori kritis tidak bisa melepaskan diri dari warisan Marxisme dalam seluruh filosofi pengetahuannya. Teori kritis pada satu pihak merupakan salah satu aliran ilmu sosial yang berbasis pada ide-ide Karl Marx dan Engels (Denzin, 2000: 279-280).

Pengaruh idea marxisme - neo marxisme dan teori kritis mempengaruhi filsafat pengetahuan dari paradigma kritis. Asumsi realitas yang dikemukakan oleh paradigma adalah asumsi realitas yang tidak netral namun dipengaruhi dan terikat oleh nilai serta kekuatan ekonomi, politik dan sosial. Oleh sebab itu, proyek utama dari paradigma kritis adalah, Pembebasan nilai dominasi dari kelompok yang ditindas. Hal ini akan mempengaruhi bagaimana paradigma kritis memcoba membedah realitas dalam penelitian ilmiah, termasuk di dalamnya penelitian atau analisis kritis tentang teks media.

Ada beberapa karakteristik utama dalam seluruh filsafat pengetahuan paradigma kritis yang bisa dilihat secara jelas.

Ciri pertama adalah ciri pemahaman paradigma kritis tentang realitas. Realitas dalam pandangan kritis sering disebut dengan realitas semu. Realitas ini tidak alami tapi lebih karena bangun konstruk kekuatan sosial, politik dan ekonomi. Dalam pandangan paradigma kritis, realitas tidak berada dalam harmoni tapi lebih dalam situasi konflik dan pergulatan sosial (Eriyanto, 2001:3-46). 
Ciri kedua adalah ciri tujuan penelitian paradigma kritis. Karakteristik menyolok dari tujuan paradigma kritis ada dan eksis adalah paradigma yang mengambil sikap untuk memberikan kritik, transformasi sosial, proses emansipasi dan penguatan sosial. Dengan demikian tujuan penelitian paradigma kritis adalah mengubah dunia yang tidak seimbang. Dengan demikian, seorang peneliti dalam paradigma kritis akan mungkin sangat terlibat dalam proses negasi relasi sosial yang nyata, membongkar mitos, menunjukkan bagaimana seharusnya dunia berada (Newman, 2000:75-87; Denzin, 2000:163-186).

Ciri ketiga adalah ciri titik perhatian penelitian paradigma kritis. Titik perhatian penelitian paradigma kritis mengandaikan realitas yang dijembatani oleh nilai- nilai tertentu. Ini berarti bahwa ada hubungan yang erat antara peneliti dengan objek yang diteliti. Setidaknya peneliti ditempatkan dalam situasi bahwa ini menjadi aktivis, pembela atau aktor intelektual di balik proses transformasi sosial. Dari proses tersebut, dapat dikatakan bahwa etika dan pilihan moral bahkan suatu keberpihakan menjadi bagian yang tak terpisahkan dari analisis penelitian yang dibuat.

Karakteristik keempat dari paradigma kritis adalah pendasaran diri paradigma kritis mengenai cara dan metodologi penelitiannya. Paradigma kritis dalam hal ini menekankan penafsiran peneliti pada objek penelitiannya. Hal ini berarti ada proses dialogal dalam seluruh penelitian kritis. Dialog kritis ini digunakan untuk melihat secara lebih dalam kenyataan sosial yang telah, sedang dan akan terjadi.

Karakteristik keempat ini, menempatkan penafsiran sosial peneliti untuk melihat bentuk representasi dalam setiap gejala, dalam hal ini media massa berikut teks yang diproduksinya. Maka, dalam paradigma kritis, penelitian yang bersangkutan tidak bisa menghindari unsur subjektivitas 
peneliti, dan hal ini. bisa membuat perbedaan penafsiran gejala sosial dari peneliti lainnya.(Newman, 2000:63-87).

Dalam konteks-karakteristik yang keempat ini, penelitian paradigma kritis mengutamakan juga, analisis yang menyeluruh, kontekstual dan multi level. Hal ini berarti bahwa penelitian kritis menekankan soal historical situatedness dalam seluruh kejadian sosial yang ada(Denzin, 2000: 170). Perkembangan teori kritis semakin jelas ketika Sekolah Frankfurt menjadi motor penggerak teori tersebut. Selain bahwa sekolah Frankfurt bersentuhan dengan perkembangan ilmu sosial kritis pada waktu itu, sekolah tersebut juga merefleksikan peran media massa pada masyarakat waktu itu. Konteks Jerman pada waktu itu juga sangat dipengaruhi oleh sejarah Jerman pada waktu pemerintahan Hitler (Nazi). Dalam perkembangan selanjutnya, Sekolah Frankfurt juga menyatakan bahwa, ternyata media bisa menjadi alat pemerintah untuk mengontrol publik, dalam arti tertentu media bisa menjadi bagian dari ideological state apparatus(Littlejohn, 2002:213). Dalam hal tertentu, media bukan adalah realitas yang netral dan bebas kepentingan, tapi media massa justru menjadi realitas yang rentan dikuasai oleh kelompok yang lebih dominan dan berkuasa (Rogers,1994:102-125). 


\section{BAB VI \\ PEMBAHASAN}

\section{A. Konten Merebaknya Hoak}

Pada kondisi pandemi seperti sekarang ini hoak makin masif dan berkembang sangat cepat. Hoak sudah merebak diberbagai lini kehidupan. Mulai dari politik, ekonomi, sosial, agama, pendidikan hingga kesehatan. Dalam bidang kesehatan ini Kominfo mencatat bahwa sejak 23 Januari hingga 18 Oktober 2020, terdapat sebanyak 2.020 konten hoax mengenai COVID-19 yang telah beredar di media sosial. Dari total konten hoax yang ada, kini sebanyak 1.759 konten telah berhasil diturunkan (take down). Dalam bidang pendidikan ditemukan pada media sosial twitter tanggal 24 Agustus 2020 yang dimuat dalam laman cekfakta.com ditemukan bahwa untuk masuk perguruan tinggi seperti Undip pada tahun 2020 mencapai angka 87 miliar.
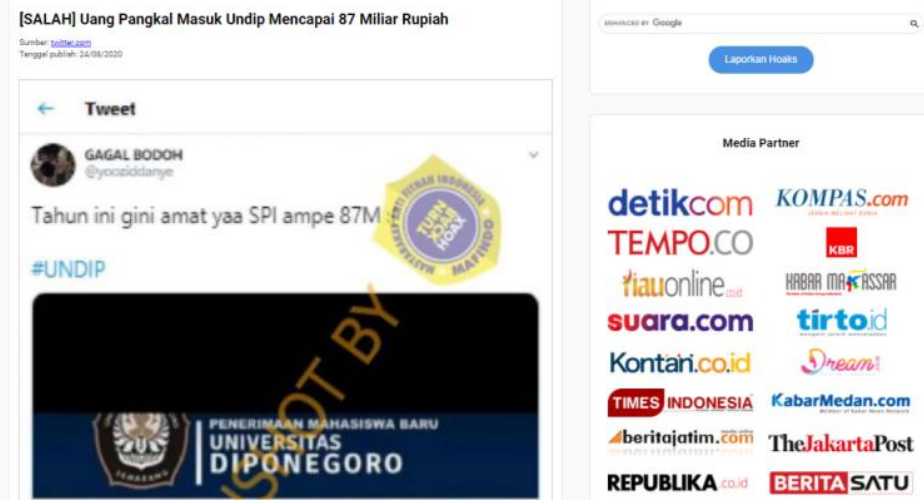


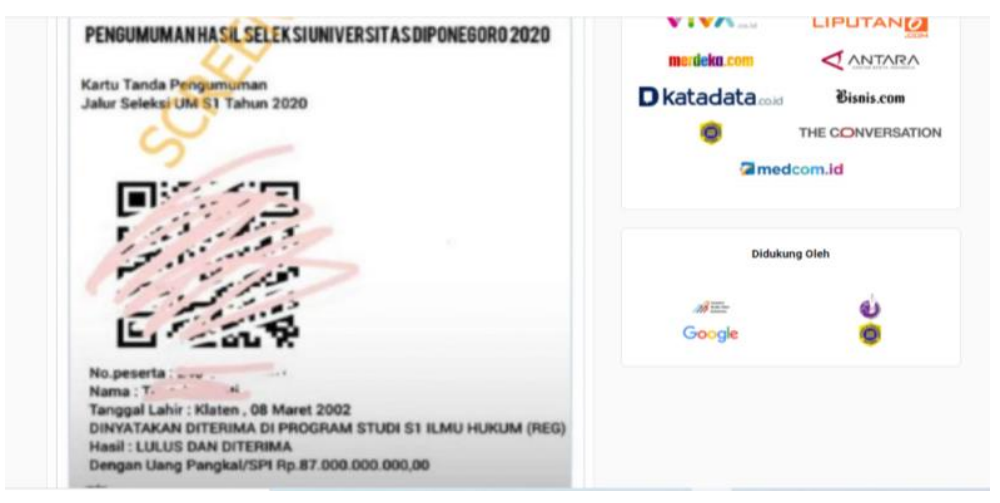

Sumber : https://cekfakta.com/focus/3978

Dalam "Hermeneutika Ricoeur" yaitu teori fiksasi ini, menjelaskan bagaimana menyampaikan dan memahami proses dari wacana lisan dibentuk ke dalam sebuah teks tulis, atau dari lisan ke penulisan. Jika makna teks mau diungkap atau dipahami, seorang penafsir akan menghadapi dua alternatif, yaitu jalan langsung yang ditempuh oleh Heiddeger atau jalan melingkar yang ditempuh oleh Husserl. Jika menggunakan jalan langsung, seorang penafsir mehamai teks secara langsung tanpa menggunakan metodologi untuk memahami dan menyelidiki makna yang terkandung dalam teks.

Dengan jalan ini, banyak pengguna media sosial, ketika menerima berita simpang siur akan langsung mempercayai tanpa menyelidiki kebenaran faktual sesuai kejadian yang seungguhnya. Seperti pada pesan dalam gambar di atas bahwa untuk masuk di perguruan tinggi harus membayar sejumlah yang cukup mahal. Pesan dalam media sosial tersebut dapat ditelaah dalam dua alternatif. Mau diterima langsung tanpa melakukan proses screening atau perlu jalan memutar dulu mengecek kebenaran atas informasi yang ada.

Jalan melingkar itu ditempuh untuk menyingkap makna tersembunyi di dalam teks. Dengan menggunakan jalan melingkar atau fenomenologi ini, seorang pengguna dan pembaca berita di media sosial akan mempertimbangkan berita 
yang mereka baca dengan menyelidiki fenomena kebenaran yang terkandung dalam teks/berita. Cara ini lebih aman dan mendalam dalam membaca sebuah berita agar terhindar dari hoax, dengan begitu seorang pembaca akan lebih nyaman dan aman dalam membaca berita. Dalam dunia digital seperti saat ini hanya segelintir orang yang menggunakan cara seperti ini karena sudah banyak berita-berita yang tidak benar namun seolah sesuai dengan keadaan yang sesungguhnya.

Pembahasan berikutnya adalah terkait dengan Menteri Perhubungan yang setelah 15 hari sembuh dari positif covid kambuh lagi. Informasi itu berkembang di beberapa media sosial, namun penulis menganalisis dari laman cekfakta.com yang terpublished pada 18 Mei 2020.

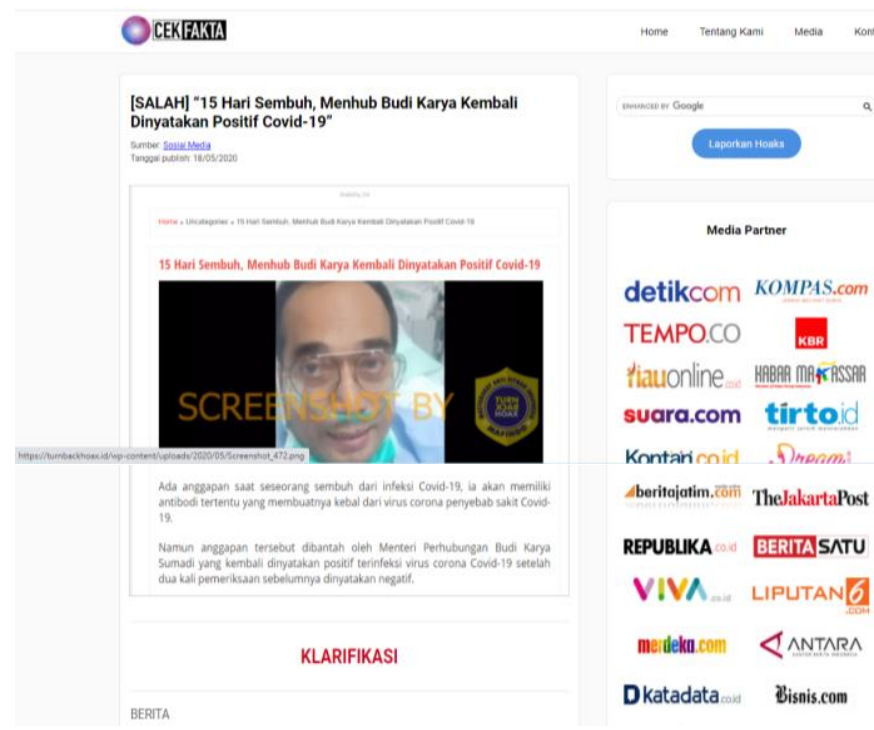

Sumber : https://cekfakta.com/focus/3978 
Gambar di atas adalah contoh infomasi hoak yang beredar di media sosial dengan narasi sebagai berikut:

"Ada anggapan saat seseorang sembuh dari infeksi Covid-19, ia akan memiliki antibodi tertentu yang membuatnya kebal dari virus corona penyebab sakit Covid19.Namun anggapan tersebut dibantah oleh Menteri Perhubungan Budi Karya Sumadi yang kembali dinyatakan positif terinfeksi virus corona Covid-19 setelah dua kali pemeriksaan sebelumnya dinyatakan negatif. Ia bercerita, usai dinyatakan sembuh dengan bukti dua kali pemeriksaan hasilnya negatif Covid-19 dan dibolehkan pulang, Menhub Budi Karya kembali diperiksa dan dinyatakan positif Covid-19, padahal ia sudah 15 hari berada di rumah.

"Masak saya di rumah saya sempat positif lagi, 15 hari setelah di rumah. Setelah itu dites lagi 2 kali negatif," ujar Menhub Budi Karya dalam diskusi di Instagram Live @tempodotco, Sabtu (16/5/2020)." (dikutip dari media narasi media sosial suara.com)

Dari narasi di atas kemudian dilakukan cek fakta diperoleh hasil bahwa :

Berdasarkan hasil penelusuran Tim Cek Fakta Tempo, klaim bahwa Menteri Perhubungan Budi Karya Sumadi kembali dinyatakan positif Covid-19 adalah klaim yang menyesatkan. Menhub Budi Karya sudah dinyatakan sembuh pada 27 April 2020. Berita di Suara.com telah mengalami perubahan. Redaksi Suara.com sudah meminta maaf dan mengganti judul artikel berita mereka Judul tersebut memunculkan tafsir bahwa Budi saat ini masih dalam kondisi terinfeksi virus Corona Covid-19. Padahal, pernyataan Budi itu diambil dari pengalamannya saat menjalani perawatan Covid-19 dan tes PCR. Tes pertama hasilnya negatif dan tes kedua, yang dijalani 15 hari setelah tes pertama, hasilnya positif. Namun, sesuai protokol kesehatan Covid-19, pasien baru dinyatakan bebas Covid-19 setelah menjalani dua kali tes PCR yang hasilnya berturut-turut negatif. Dengan demikian, ketika itu, Budi belum dinyatakan sembuh dari Covid-19 dan masih dalam perawatan.Menurut juru bicara Kementerian Perhubungan, Adita Irawati, sesuai protokol kesehatan Covid-19, pasien baru dinyatakan bebas Covid-19 setelah menjalani dua kali tes polymerase chain reaction (PCR) yang hasilnya berturut-turut negatif, bukan satu kali. "Menhub dinyatakan positif kembali ketika masih dalam perawatan dokter RSPAD," katanya seperti dikutip dari Kompas.com.

Adita pun menyatakan bahwa pemberitaan yang menyebut Menhub Budi Karya kembali positif Covid-19 menyesatkan. Menurut Adita, dilansir dari Liputan6.com, Budi saat ini dalam kondisi sehat dan telah aktif kembali sebagai Menhub sejak 27 April 2020. RSPAD menyatakan hasil dua tes PCR terakhir Budi membuktikan bahwa ia telah bebas Covid-19. 
Dalam keterangannya, Adita juga menceritakan kronologi sejak Budi terkonfirmasi positif Covid-19 hingga dinyatakan sembuh. Pada 14 Maret 2020, Budi dinyatakan positif Covid-19 dan menjalani perawatan di RSPAD. Setelah dirawat beberapa hari, Budi menjalani tes PCR pertama dan hasilnya negatif. Lima belas hari kemudian, Budi menjalani tes PCR kedua. Namun, hasilnya kembali positif. Karena itu, Budi masih harus menjalani perawatan karena dua kali tes PCR berturut-turut menunjukkan hasil negatif dan positif. Menurut Adita, Budi baru dinyatakan bebas Covid-19 pada 27 April 2020.

Tempo kemudian memeriksa berita di Suara.com yang dikutip oleh situs Siraman.info. Isi artikel Siraman.info memang serupa dengan isi berita Suara.com. Namun, berita di Suara.com telah mengalami perubahan. Hal ini diketahui dari catatan redaksi pada bagian bawah berita.

Dalam catatan redaksi itu, tertulis: "Artikel ini sebelumnya dimuat dengan judul '15 Hari Sembuh, Menhub Budi Karya Kembali Dinyatakan Positif Covid-19'. Artikel mengalami perubahan judul menjadi 'Saat Ini Sehat Bugar, Menhub BKS Sempat Dua Kali Dinyatakan Positif Covid-19' karena judul pertama bisa salah tafsir. Menhub Budi Karya Sumadi saat ini sudah dalam kondisi sehat. Penjelasan ini sekaligus sebagai bentuk tanggung jawab kami sesuai dengan Pedoman Pemberitaan Media Siber. Kami mohon maaf atas ketidaknyamanannya. Terima kasih."

Rujukan

https:/turnbackhoax.id/2020/05/18/salah-15-hari-sembuh-menhub-budi-karya-kembalidinyatakan-positif-covid-19/

Dalam analisis fiksasi bahwa hal intepretasi pesan akan bisa ditelaah dengan dua hal. Langsung dicerna informasinya atau melalu proses pemahaman dulu.

Artinya bahwa pesan tersebut jika akan dimaknai secara langsung tanpa memperdulikan kebenarannya akan memberi informasi bahwa Menteri Perhubungan yang positif seakan tidak sembuh setelah menjalani pemeriksaan. Dan ini akan berdampak personal yang bersangkutan dan juga masyarakat yang bisa jadi juga mengalami positif covid yang sama.

Oleh karenanya kemudian ada counter laman/situs yang memberi klarifikasi atas informasi tersebut. Suara.co sebagai media terintegrasi telah melakukan klarifikasi dan sebagai salah satu rujukan atau counter akan narasi hoak yang beredar 
dan memberikan jawaban atas kebenaran yang sesungguhnya terjadi.

Dalam bidang poliitk hingga akhir tahun 2020, hoak menjadi sebuah komoditas baru karena ada momentum pilkada serentak yang digelar serentak pada 9 Desember. Ini terbukti menimbulkan masalah dan meresahkan masyarakat, karena memberikan informasi yang salah.

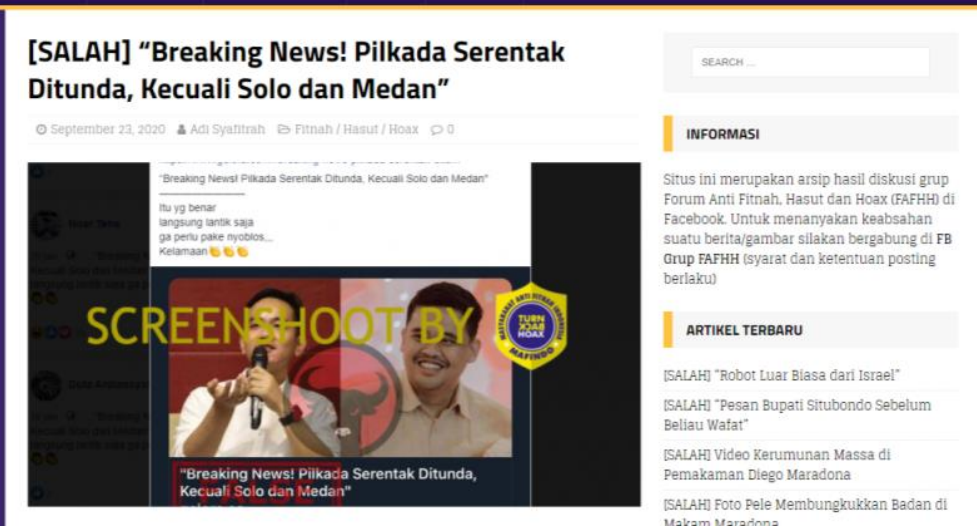

https://turnbackhoax.id/2020/09/23/salah-breaking-news-pilkada-serentakditunda-kecuali-solo-dan-medan/

Adanya pesta demokrasi seperti pilkada serentak memicu antar kontestan justru berlomba memanfaatkan situasi dengan memojokkan lawan-lawan politiknya melalui informasi hoak. Informasi sebagai anak dan manantu orang nomor satu di Indonesia pasti akan menjadi sorotan publik. Apalagi keduanya menjadi calon kepala daerah di dua kota besar seperti Solo dan Medan. Meski keduanya dinyatakan menang dan terpilih sesuai dengan daerahnya masing-masing, yakni Solo dan Medan. 
Kontestasi itu kemudian dimanfaatkan oleh orang-orang tertentu dengan menyebarkan informasi yang tidak ada kebenarannya. Hoak dengan memunculkan narasi-narasi yang mempropaganda keadaan di dunia maya menjadi heboh. Dalam informasi hoak tersebut memberikan narasi bahwa pilkada serentak akan ditunda kecuali Solo dan Medan. Informasi itu seakan menguatkan bahwa pilkada hanya milik dinasti yang sekarang berkuasa yaitu presiden Joko Widodo. Namun setelah dilakukan cek fakta, diperoleh penjelasan dan hasil sebagai berikut :

Berdasarkan hasil penelusuran, klaim bahwa Pilkada serentak 2020 ditunda kecuali Solo dan Medan adalah klaim yang salah. Teori dalam fiksasi meggambarkan dunia politik dengan melibatkan anak dan mantu orang nomor satu di negeri ini menjadi konsumsi yang menarik untuk mendapatkan simpati publik. Bagi si penebar hoak mendapat simpati masyarakat adalah hal utama yang menjadi tujuannya. Teori fiksasi dengan jalan pintas dan langsung mendapat respon, bahkan langsung menyebarkannya harapan, karena jalan yang diambil adalah jalur dari Heideger. Tidak menggunakan jalur Russel dengan memahami dan menggunakan jalur agak memutar.

Faktanya, Pilkada serentak 2020 di 270 wilayah kabupaten/kota dan provinsi tetap dilanjutkan tanpa terkecuali. Isi artikel yang dimuat di situs gelora.co itu hanya berisi candaan dan sindiran pada pemerintah yang ngotot tetap melanjutkan Pilkada serentak 2020 di tengah pandemi covid-19.

Contoh berikutnya adalah tentang adanya surat gubernur Sumatra Utara minta dana pengamanan pelaksanaan pilkada sebagai berikut ; 


\section{[SALAH] Surat Gubernur Sumatera Utara Minta Dana Pengamanan Pilkada 2020}

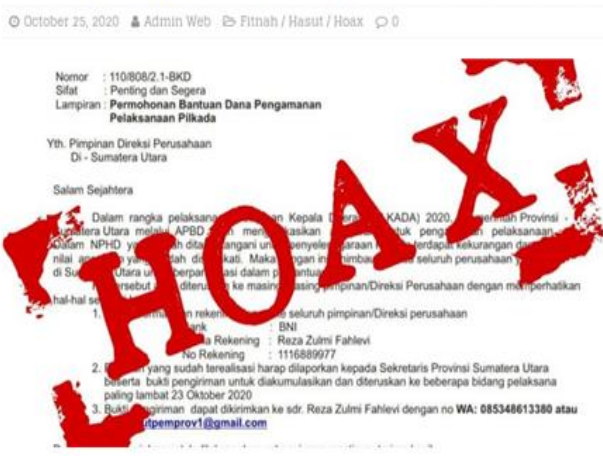

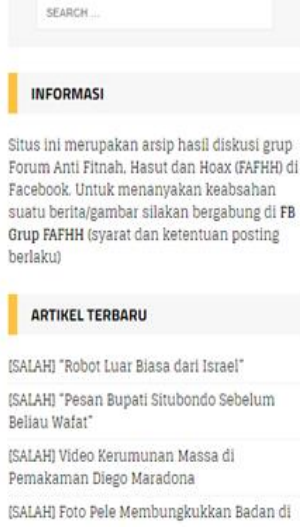

https://turnbackhoax. id/2020/10/25/salah-surat-gubernur-sumatera-utara-mintadana-pengamanan-pilkada-2020

Dari informasi tersebut di atas kemudian dilakukan cek dan ricek dan membuahkan hasil. Berikut penjelasannya ;

Beredar sebuah surat mengatasnamakan Gubernur Sumatera Utara, Edy Rahmayadi. Dalam surat tersebut berisi tentang permohonan bantuan dana pengamanan pelaksanaan Pilkada 2020 ditujukan kepada Pimpinan Direksi Perusahaan di Sumatera Utara. Surat yang dikeluarkan tanggal 20 Oktober 2020 tersebutmenyebut Pimpinan Direksi Perusahaan agar dapat mengirim dana ke nomor rekening BNI 1116889977 atas nama Reza Zulmi Fahlevi.

Berdasarkan penelusuran, surat tersebut palsu dan tidak benar dikeluarkan oleh Gubernur Sumatera Utara, Edy Rahmayadi. Hal ini dinyatakan oleh akun resmi Humas Sumut di sosial media Facebook yang menyatakan bahwa surat tersebut tidak benar.

"Ramai beredar surat edaran yang mengatas namakan Gubernur Sumatera Utara Edy Rahmayadi, terkait permohonan bantuan dana pengamanan Pilkada, dengan ini kami informasikan bahwa surat edaran tersebut adalah tidak bendr, dan mohon untuk tidak menyebarkanya, "tulis akun resmi Humas Sumut pada Sabtu (24/10/2020).

Dengan demikian, suratyang mengatasnamakan Gubernur Sumatera Utara, Edy Rahmayadi meminta bantuan dana pengamanan Pilkada 2020 tidak benar dan masuk dalam kategori konten palsu.

$====$

Referensi:

https://www.facebook.com/birohumas.../posts/4565269493546214 [불 (Ctrl) - 
Beberapa contoh di atas adalah segelintir gambaran nyata bahwa hoax beredar disekitar kita. Bahkan berkembang dari waktu ke waktu terus mengalami kemajuan yang berarti.

\section{Merebaknya informasi hoak}

Muncul hoaks atau informasi yang tidak jelas memberikan kebingungan pada masyarakat luas. PBB menyatakan bahwa hoaks berkembang menjadi misinformasi, malinformasi dan disinformasi. Kenyataannya yang terjadi saat ini adalah muncul hoaks begitu masif. Korban hoaks ini seakan tak pernah berhenti. Bahkan setiap bulan mengalami peningkatan yang berarti.

Mafindo mencatat, ada jumlah yang besar terkait peredaran hoak, khususnya terkait dengan wabah COVID19

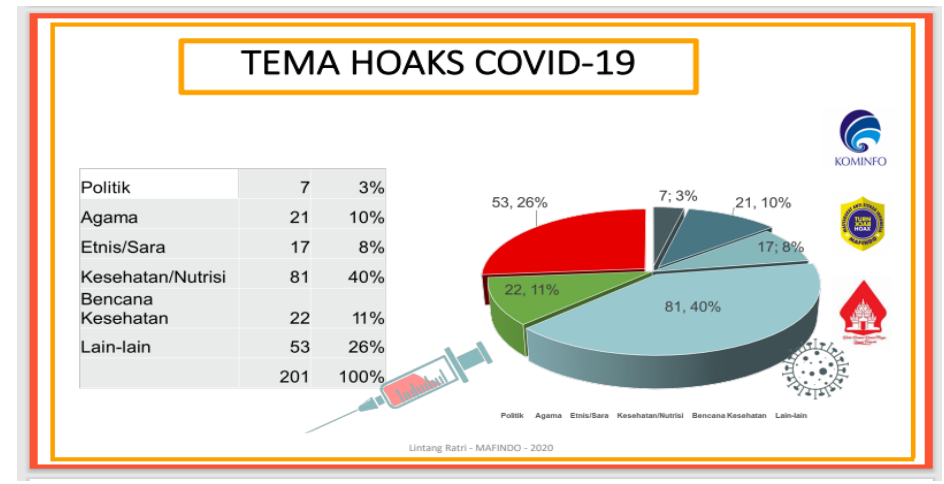

Sumber (Litbang Mafindo,2020)

Mafindo mencatat bahwa hoak terkait dengan COVID-19 didominasi oleh bidang kesehatan mencapai $40 \%$, bencana kesehatan $11 \%$, agama $10 \%$, etnis/ sara $8 \%$, politik $3 \%$, dan sisanya $26 \%$.

Pada peristiwa lain juga terjadi dalam beberapa platfom media sosial seperti whatsapp. Berikut adalah contoh pesan berantai yang diberikan oleh salah seorang teman, kemudian dishare ke komunitas-komunitas, maupun 
grup. Setelah dilakukan penelusuran ternyata infomasi hoak. :

Budi, Catur, D8sat, Mardi...
Tolong bantu dikasih tahu
ke saudara ${ }^{2}$ kita yg kena
covid $19 .$.
Ini obat pemberian dari
TUHAN yg mudah didapat
yg sangat manjur..
1 biji air kelapa muda
1 biji jeruk nipis diperas
1 sendok makan garam
2 sendok madu
Semuanya diaduk dan
diminum airnya... dijamin
1 jam kemudian virusnya
akan hilang....
Mudah mudahan semua
dalam keadaan sehat
walafiat..

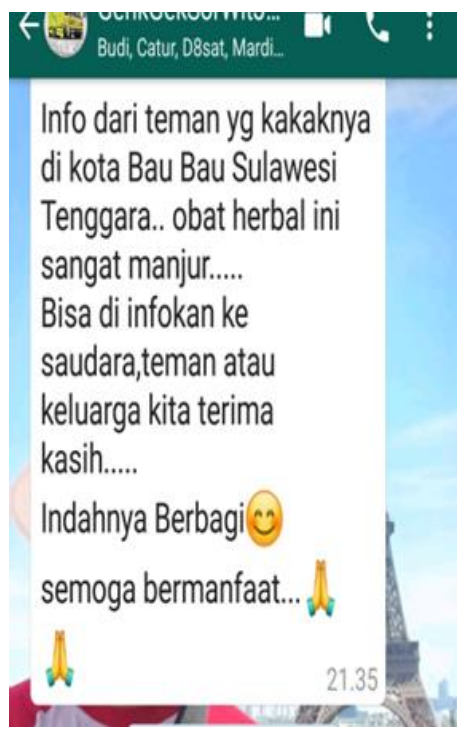

Sumber ; (Sumardi,2020)

Setelah dilakukan dengan salah satu tools atau alat chatboth whatsapp Kalimasada Mafindo diperoleh bahwa ternyata informasi tersebut adalah salah atau tidak benar. Berikut hasil penelusurannya ;

17:21 Malatindo Kalimasada
Temuan 1 dari 2: [SALAH]
Campuran Air Kelapa Muda,
Jeruk Nipis, dan Garam
Dapat Mematikan Virus
Corona
Status
Misleading Content
Fakta
Akun Facebook Ita Yurita
mengunggah narasi
yang menginformasikan
bahwa campuran air
kelapa, air perasan jeruk
nipis, dan garam dapat
menghilangkan virus
Covid-19 dalam waktu 1 jam
setelah diminum.
Berdasarkan hasil
penelusuran, informasi

17:21 :at:ina
Mafindo Kalimasada
penelusuran, informasi
pada unggahan tersebut
tidak benar. Dikutip dari
portal Liputan6, Farmakolog
Universitas Gadjah Mada
(UGM) Prof. Dr. Zullies
Ikawati, Apt mengatakan
kabar tersebut belum
terbukti secara klinis,
sehingga masyarakat
diminta untuk tidak mudah
menerima informasi yang
belum terbukti itu.
"Jika ada kabar-kabar
begitu saja yang belum ada
buktinya, sebaiknya tidak
langsung diterima," kata
Zullies saat berbincang
dengan Liputan6.com.
Guru Besar Fakultas
Farmasi I IfM tersehıt

Sumber : (Triyono,2020) 

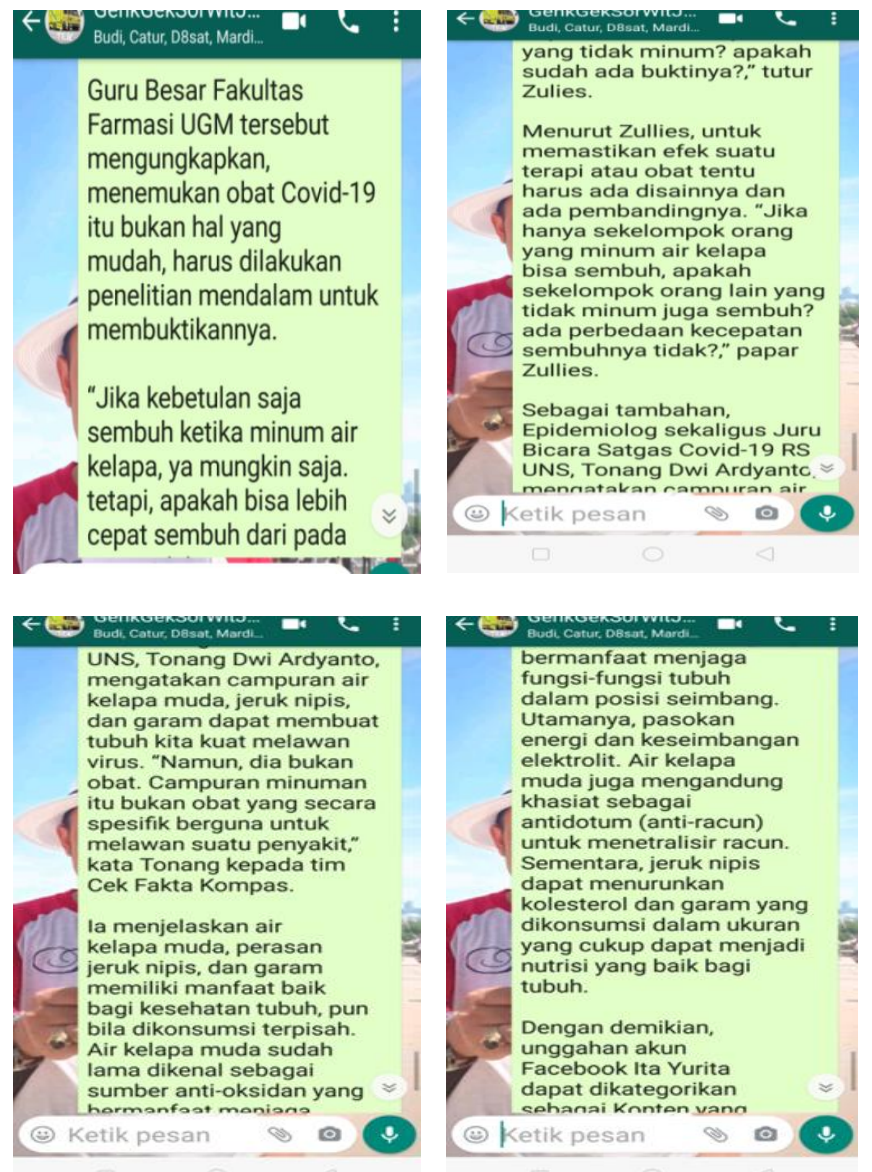

Sumber : (Triyono,2020)
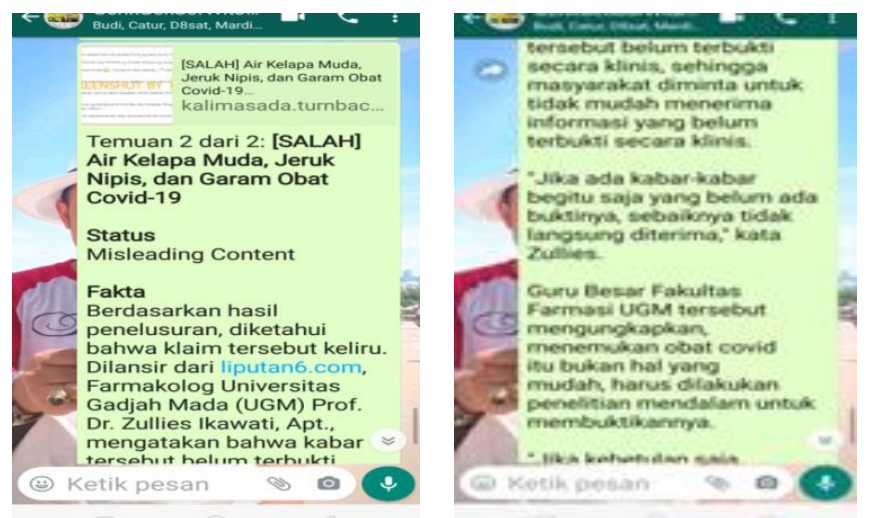


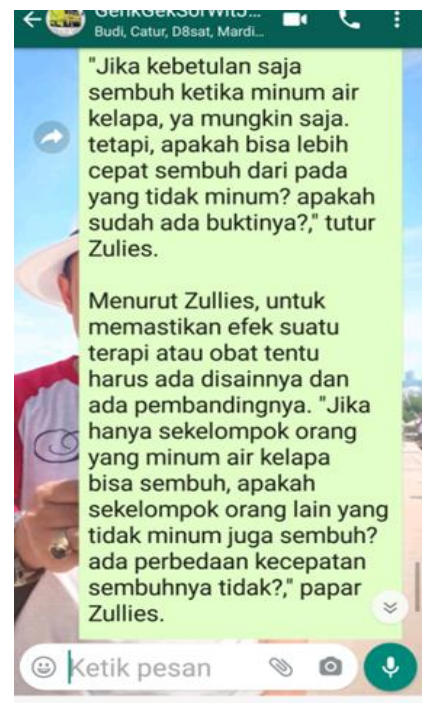

Sumber : (Triyono,2020)
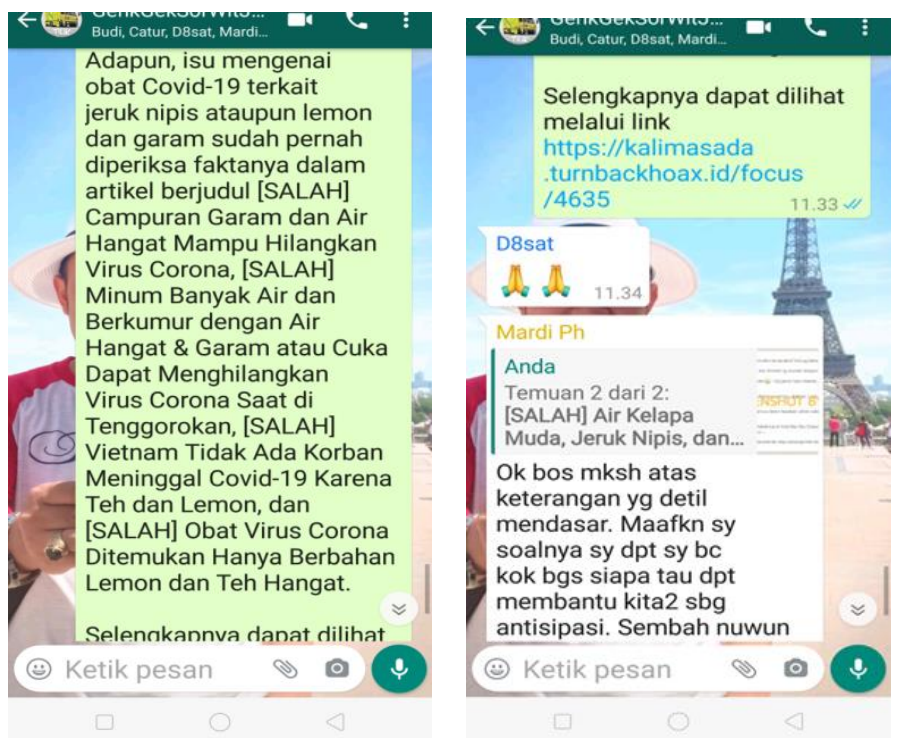

Sumber : (Triyono,2020)

Disamping hoak terkait dengan wabah corona, juga tidak kalah hebohnya dengan informasi lain yang terus merebak dan membanjiri dalam kehidupan masyarakat. 
Kenyataan ini membuat masyarakat menjadi sangat bingung, untuk memilih informasi atau berita mana yang layak untuk diterima. Bahkan banyak yang menggunakan informasi itu bagikan pada kelompok atau komunitas mereka. Dalam bidang pendidikan misalnya, banyak kejadian hoak yang "berkeliaran" diberbagai sekolah maupun institusi pendidikan lainnya. Sebagai contoh banyak hoak yang mengatasnamakan pimpinan perguruan tinggi meminta dosen dan pengajar untuk mengikuti workshop dan seminar dengan membayar sejumlah uang. Fenomena ini kerap terjadi diberbagai wilayah di Indonesia. Bahkan tak jarang membawa korban yang jumlahnya tidak sedikit. Dengan embel-embel nama pejabat dan dari sebuah institusi ternama, mereka mencari sasaran dengan imingiming sertifikat, peghargaan, kemudahan kenaikan jabatan dan lain sebagainya. Anehnya hoak seakan seperti asli dari orang yang membuatnya. Namun, kalau diteliti dan dilakukan cross cek ternyata tidak benar. Lebih ironis lagi mereka tahu persis nama pejabatnya, gelarnya dan posisinya yang strategis sehingga sangat mudah untuk dapat mempengaruhi sasarannya.

Dibidang kesehatan, kita melihat banyak orang mudah menjadikan informasi yang beredar di dunia maya menjadi referensi dalam hal-hal kesehatan. Contoh air kelapa dikasih garam akan menyembuhkan COVID 19. Dan informasi ini dikemas dengan sangat baik dan mampu mempengaruhi siapa saja yang membacanya di media sosial. Banyak orang yang mempercayai ini, hingga informasi ini begitu viral dijagat dunia maya. 
Kita cermati informasi berikut ini :

Wabah virus korona semakin meluas menjangkit di beberapa negara. Sayangmya, banyak pula kabar hoax di masyarakat yang membuat resah. Misalnya saja salah satu informasi dari pesan berantai di WhatsApp Group, yang menjelaskan bahwa air garam dapat dijadikan obat pencegah virus korona (coronavirus/2019-nCov).

Informasi ini dijelaskan Ahli Paru-Paru China, Zhong Nanshan, yang merupakanpenemuvirus korona SARS pada 2003 silam. Dia menyarankan beberapa cara yang bisa Anda lakukan untuk mencegah virus korona. Berikut isi pesannya: (seorang ahli paru-paru Cina yang menemukan virus corona SARS pada 2003) menyarankan cara-cara sederhana untuk mencegah pneumonia Wuhan:

Dianjurkanagar Anda berkumur dengan air garam ringan sebelum pergi ke rumah sakit atau tempatumum lainnya (dan melakukan hal yangsama setelah kembali ke rumah). Metodenya adalah sebagai berikut:

a) Memegang seteguk air garam encer.

b) Angkat kepalamu; biarkan air garam tetap di sekitar area tenggorokan Anda.

c) Buka mulut sedikit dan buang napas perlahan, biarkan udara menggelegak melalui air di tenggorokan Anda dan buatlah suara "ha".

d) Muntahkan air garam setelah beberapa detik.

e) Ulangi cara ini sebanyak 3-5 kali.

Karena virus atau bakteri mengintai di faring melalui saluran hidung, air garam encer dapat membumi mereka di tempat, sehingga mencapai tijuan mencegah infeksi.

Selama SARS, saya mempromosikan dan mengawasi metode ini di antara murid-murid saya. Akibatnya, tidak ada siswa kami di kelas kami yang kedinginan, batuk, dan demam.

Metode ini sederhana, efektif, mudah dilakukan. Tetapi membutuhkan ketekunan.

Zhong Nanshan

https://ifestyle.okezone.com/read/2020/02/05/481/2163669/menguji-

kebenaran-air-garam-untuk-tangkal-virus-korona

\section{a. Apa yang seharusnya dilakukan?}

Berbagai peristiwa hoaks yang menimbulkan keresahan masyarakat ini, begitu menjadi permasalahan yang sangat berat. Apa yang mesti dlakukan dalam mengatasi hal ini. Seharusnya hoaks harus dicegah dengan berbagai daya dan upaya. Koordinasi antar lembaga, pemangku kepentingan/stakeholders harus mampu bersatupadu menyelesaikan hoak ini. Peran pemerintah pusat, dalam hal ini kontribusi Kementerian Komunikasi \& Informasi (Kominfo) harus menjadi garda depan dalam memerangi hoak. Pemerintah daerah dari 
level propinsi, kabupaten maupun kota juga harus giat menggerakkan sendi-sendi organisasi yang ada di wilayahnya untuk memerangi hoak. Kelompok masyarakat, organisasi, partai politik, Pers, tokoh agama, kelompok usaha/bisnis, lembaga legislatif, lembaga yudikatif, NGO/LSM dan semua pihak harus mampu bersatu memberantas hoak, karena sudah sangat meresahkan masyarakat banyak.

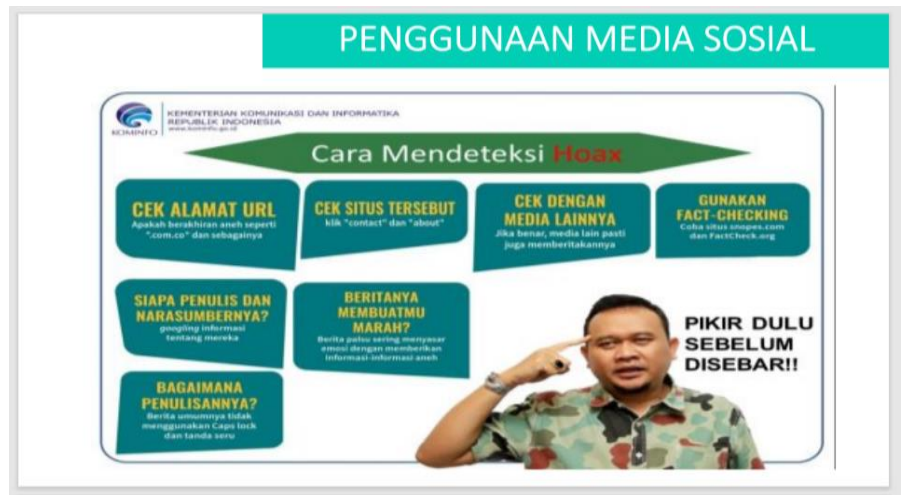

Sumber : (Litbang Mafindo,2020)

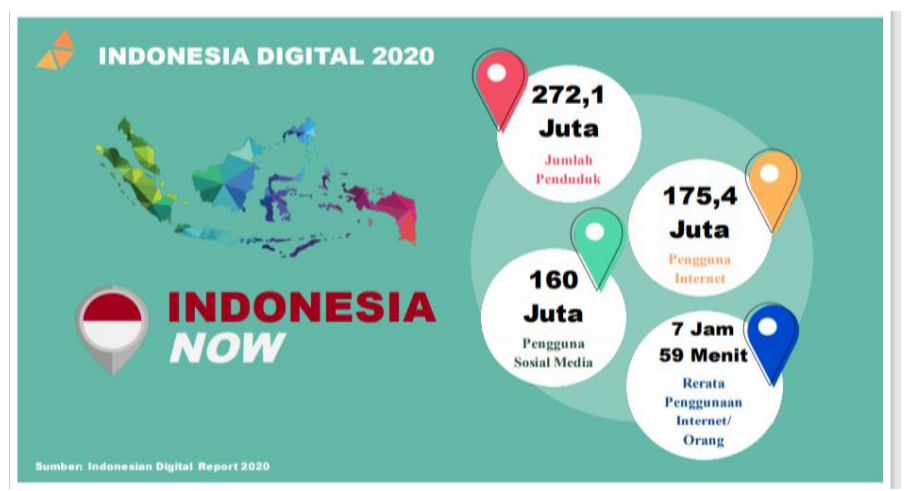

Sumber : Sumber : (Litbang Mafindo,2020)

Munculnya hoaks itu memberi implikasi pada berbagai sektor politik, sosial, ekonomi, kesehatan, agama dll. Peningkatan informasi hoaks sangat tajam dan berkembang pesat. 
Muncul istilah infodemik menjadi hal baru dalam memberi informasi dalam dinamisasi hoaks. Diantaranya adalah Disinformasi, Malinformasi, dan Misinformasi.

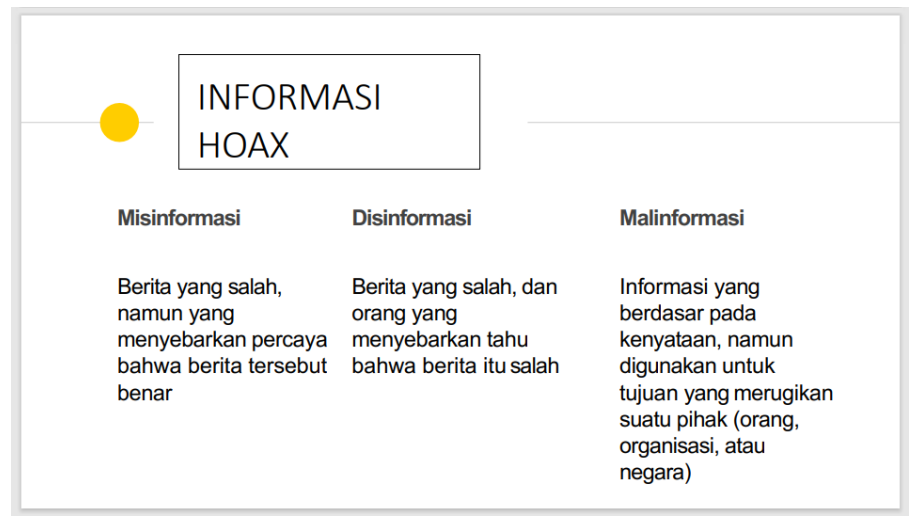

Sumber : (Litbang Mafindo,2020)

Pertama adalah Disinformasi. Adalah informasi salah yang disebarkan oleh orang yang tahu bahwa informasi itu salah dan dilakukan dengan sengaja. Dalam beberapa peristiwa muncul disinformasi terjadi dalam masyarakat kita. Berikut contoh-contoh terkait dengan disinformasi ;

1) Video meninggalnya dalang Ki Seno Nugroho

14

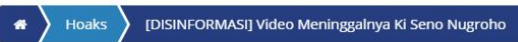

[DISINFORMASI] Video Meninggalnya Ki Seno Nugroho
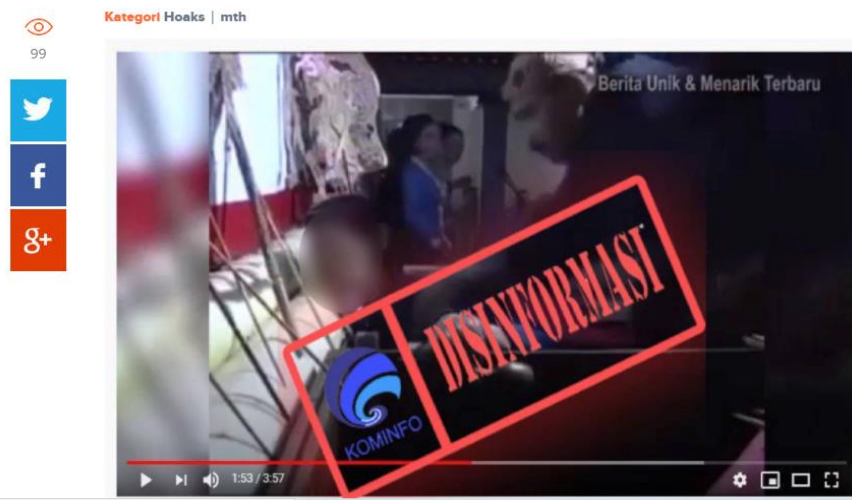

Sumber : (Kominfo,2020) 


\section{Informasi yang beredar :}

Beredar dengan masif video dengan memperlihatkan seorang dalang yang sedang membawakan lakon cerita wayang kulit di atas panggung. Tiba-tiba, dalang tertunduk dan mengeluarkan suara aneh. Kejadian tersebut diklaim sebagai detik-detik meninggalnya dalang Ki Seno Nugroho.

\section{Faktanya :}

Dalang yang meninggal di atas panggung tersebut adalah Rahmad Santoso. Dia meninggal saat pentas di Dusun Gedoro, Cepoko, Ngrambe, Ngawi, Jawa Timur, pada 2018. Sementara itu, Ki Seno meninggal di RS PKU Muhammadiyah Gamping pada 3 November 2020.

\section{Link Counter:}

https://www.jawapos.com/hoak-atau-bukan/07/11/2020/salah-video-meninggalnya-ki-senonugroho/

https://www.kominfo.go.id/content/detail/30864/disinformasi-video-meninggalnya-ki-senonugroho/O/laporan_isu_hoaks/

2) Piala Penghargaan dari WHO untuk Menkes Terawan (periode 2019-2020)

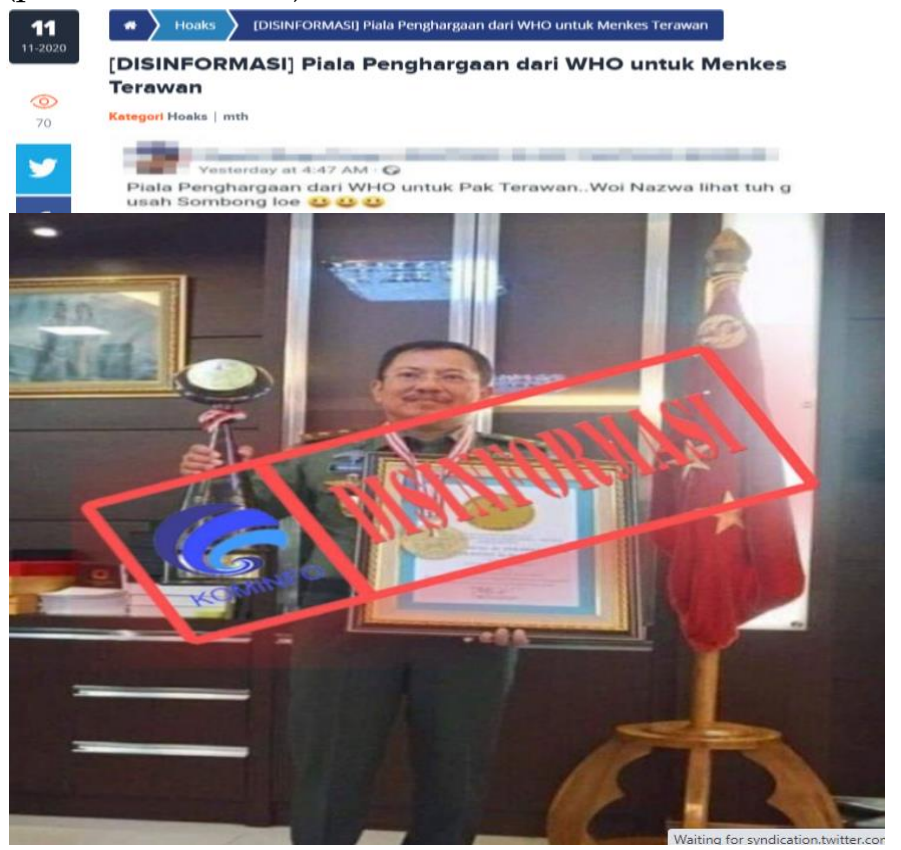

Sumber : (Kominfo,2020) 


\section{Informasi yang beredar :}

Beredar unggahan sebuah gambar yang memperlihatkan Menteri Kesehatan Republik Indonesia (periode 2019-2010), dr. Terawan Agus Putranto sedang memegang piala penghargaan. Unggahan itu disertai narasi yang menyebutkan foto tersebut merupakan foto Menkes Terawan yang mendapatkan penghargaan dari Organisasi Kesehatan Dunia (World Health Organization) atau WHO. Berdasarkan hasil penelusuran, klaim pada unggahan gambar tersebut adalah salah.

\section{Faktanya :}

Foto tersebut diabadikan pada saat dr. Terawan menerima penghargaan berupa Lifetime Achievement Award dari Ketua Umum Leprid Paulus Pangka di RSPAD Gatot Soebroto Jakarta pada 17 Juni 2019. Lembaga Prestasi Indonesia-Dunia (Leprid) memberikan apresiasi berupa Lifetime Achievement Award kepada Kepala Rumah Sakit Pusat Angkatan Darat (RSPAD) Gatot Soebroto Jakarta, Mayjen TNI Dr. dr. Terawan Agus Putranto, Sp. Rad (K) RI. Apresiasi ini diberikan atas prestasi dr.Terawan sebagai penemu metode "cuci otak" (brain wash) dengan modifikasi program Digital Subtraction Angiography (DSA) untuk penyakit stroke.

Link Counter:

https:/Www.instagram.com/p B0p5GNgn-Xf

http://rekor-leprid org index.php/2019/07/17/lifetime-achievement-award-atasprestasi-penemu-metode-cuci-otak-brain-wash-dengan-modifikasi-program-digital-

substraction-angiography-sda-untuk-penvakit-stroke-sejak-tahun-2005/

https://daerah.sindonews.com/artikel jateng 7129 dokter-terawan-raih-lifetimeachievement-award-dari-leprid 
3) Pemilik SIM C dapat bantuan Covid-19

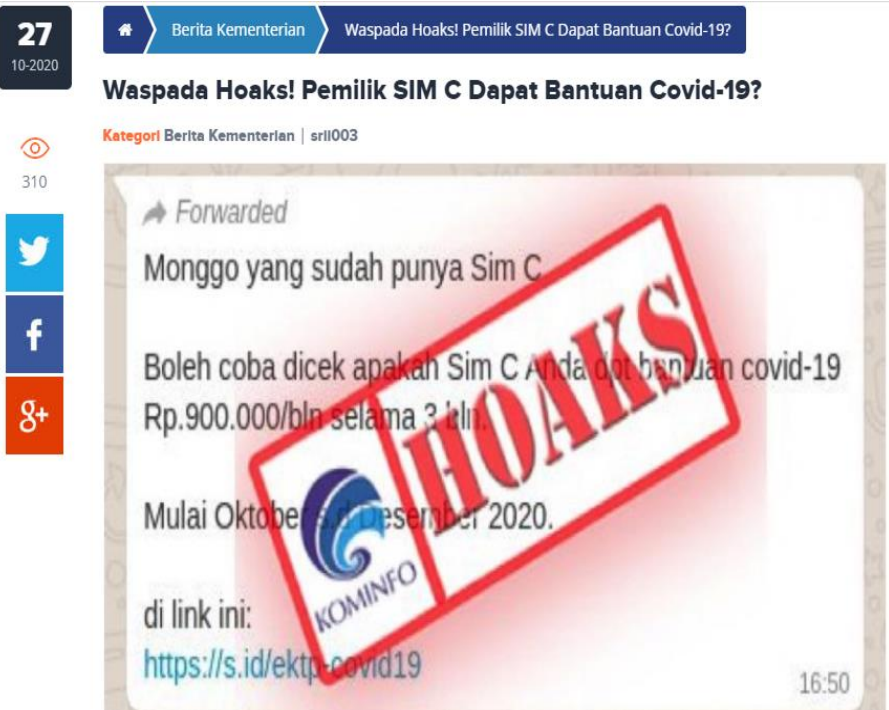

Sumber : (Kominfo,2020)

Informasi yang beredar :

Beredar pesan instan melalui Broadcast WhatsApp berisi informasi tentang cara mengecek pemilik Surat Izin Mengemudi (SIM) C yang mendapatkan bantuan Covid-19. Dalam pesan itu dituliskan, pemilik SIM C bisa mengetahui dapat bantuan Covid-19 RP 900 ribu per bulan selama 3 bulan, dengan cara mengunjungi tautan yang disertakan.

\section{Faktanya :}

Setelah ditelusuri Tim AIS Kementerian Komunikasi dan Informatika, diketahui informasi yang beredar tersebut tidak benar atau hoaks. AIS ialah mesin crawling konten negatif di internet yang diluncurkan sejak tahun 2018. Mesin AIS menggunakan artificial intelligence (AI) untuk secara cepat menentukan konten negatif. 
Tautan dalam pesan tersebut tidak terdapat formulir yang akan diisi untuk mengetahui pemilik SIM C mendapat bantuan Covid-19, melainkan muncul foto potongan iklan rokok bertemakan jin dan disertai tulisan "NGIMPI!!!". Dapat dipastikan klaim bantuan dana Covid-19 pada pesan berantai tersebut hanyalah lelucon semata.

Sebelumnya, informasi klaim bantuan dana atau kompensasi ditengah pandemi Covid-19 dengan tautan serupa juga pernah diidentifkasi sebagai konten hoaks oleh Kementerian Kominfo dalam situs resminya.

\section{Link Counter :}

hitps:/ /www.kominfo.go.id content detail 30424 waspada-hoaks-pemilik-sim-c-dapatbantuan-covid-190 oberita satker

Kedua : Yang kedua Malinformasi. Adalah Informasi berdasarkan realitas tetapi digunakan untuk merugikan, organisasi, lembaga atau bahkan negara. Contoh data pribadi seperti nama dan alamat rumah pasien pertama covid 19 di Indonesia disebarkan di media sosial. Beberapa contoh-contoh berikut adalah ; 
1) Undangan Sosialisasi

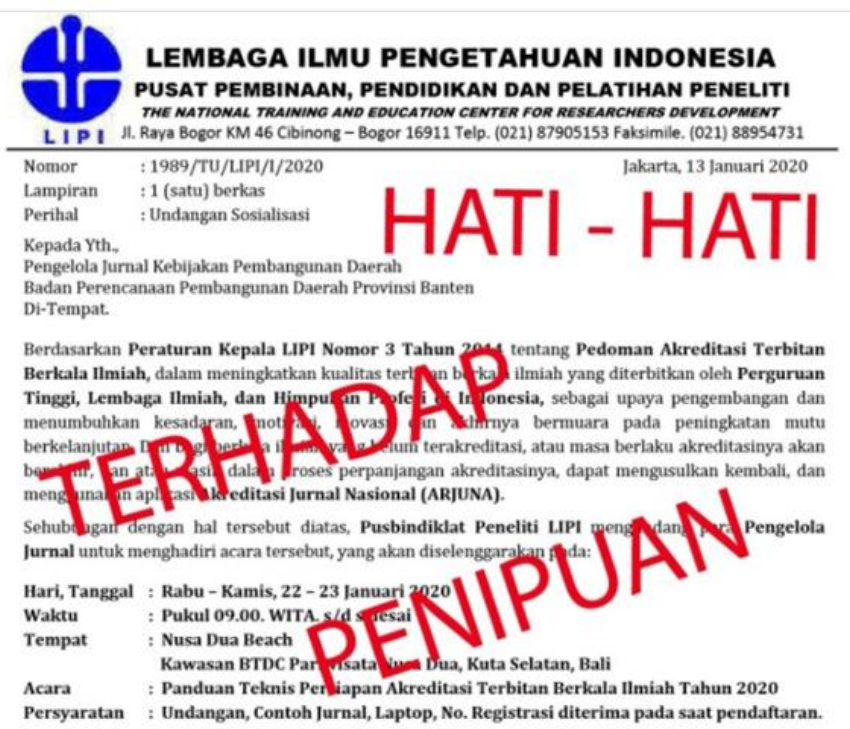

Biaya Transportasi dan Akomodasi Hotel para peserta, ditanggung dan bersumber pada Anggaran DIPA Pusbindiklat Peneliti LIPI Tahun Anggaran 2020. Dan dikirim secara online melalui rekening bank masing-masing peserta.

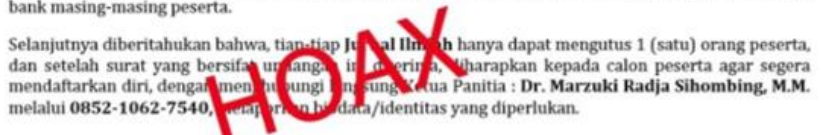

Demikian untuk maklum, ătas perhatian dan kerjasama yang baik diucapkan terima kasih.

Tembusan :

1. Kepala LIPI (sebagai laporan)

2. Arsip, -

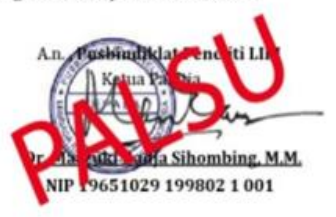

Sumber : (Kominfo,2020)

Counter :

http://pusbindiklat.lipi.go.id/id/hati-hati-terhadap-surat-palsu-penipuan-yang$\underline{\text { mengatasnamakan-lipi/ }}$ 
2) Himbauan Dispenduk Surabaya

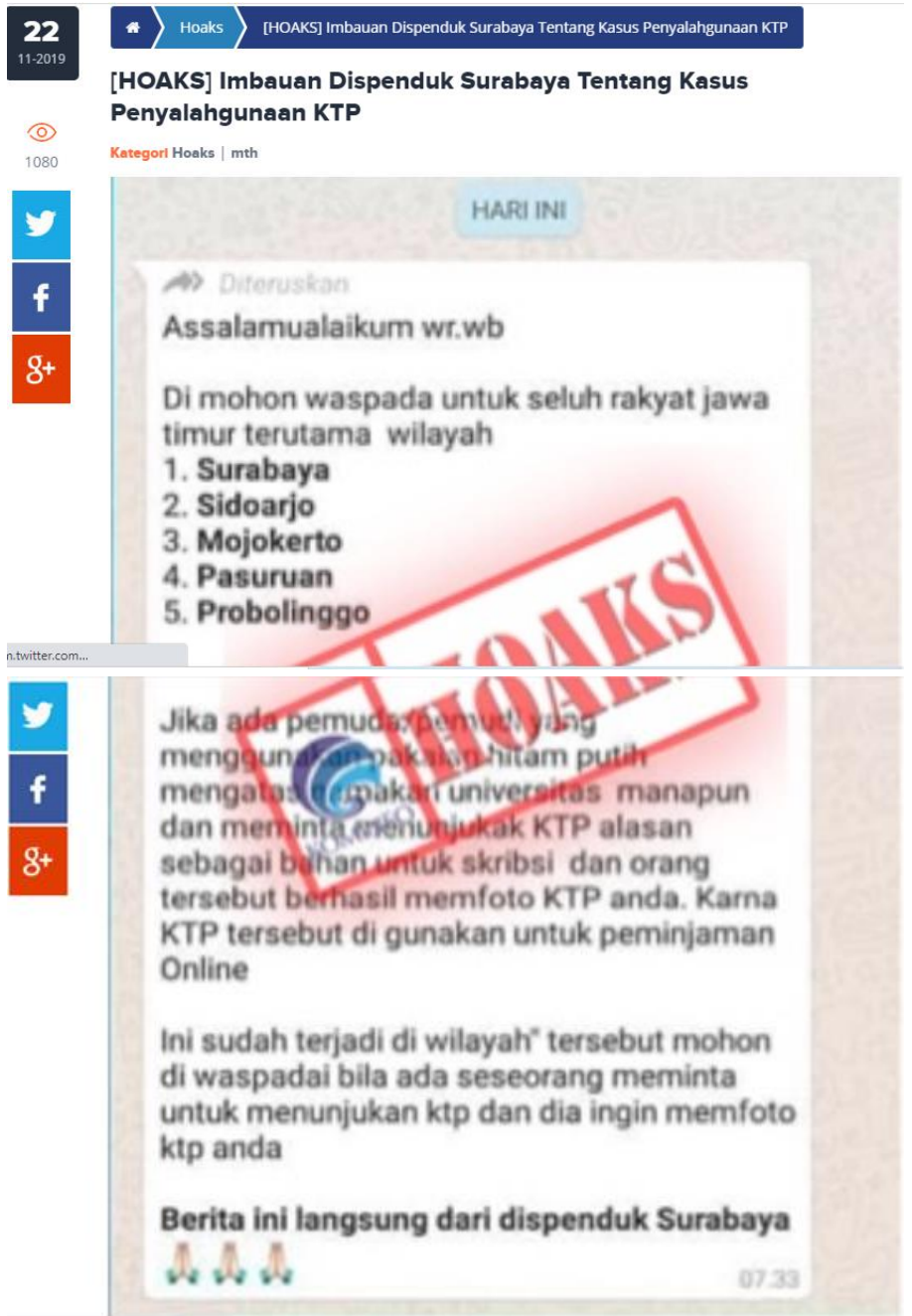

Sumber : (Kominfo,2020)

Informasi yang beredar :

Beredar pada platform whatsApp sebuah pesan berantai berupa himbauan kepada masyarakat Jawa Timur terkait modus penyalahgunaan E-KTP untuk pinjaman online yang dilakukan oleh pelaku yang 
berpura-pura sebagai mahasiswa. Informasi tersebut diklaim berasal dari Dispenduk Surabaya.

\section{Faktanya :}

Informasi berupa pesan berantai tersebut tidak memiliki sumber yang kredibel dan bukan dari "Dinas Kependudukan dan Pencatatan Sipil (DISPENDUKCAPIL) Surabaya”. Pihak DISPENDUKCAPIL Surabaya menghimbau agar masyarakat tidak mempercayai informasi tersebut dan tetap berhati-hati dalam menerima berita atau himbauan yang mengatasnamakan OPD Pemerintah Surabaya.

Link Counter:

http:/dispendukcapil.surabava.go.id/berita/492-shirojutsu https://www.instagram.com/p/B5HXns3DLPv/?igshid=8v0wx3zz49u8

https://www.instagram.com/dispendukcapil.sby/

3) Pandemi Corona sudah berakhir

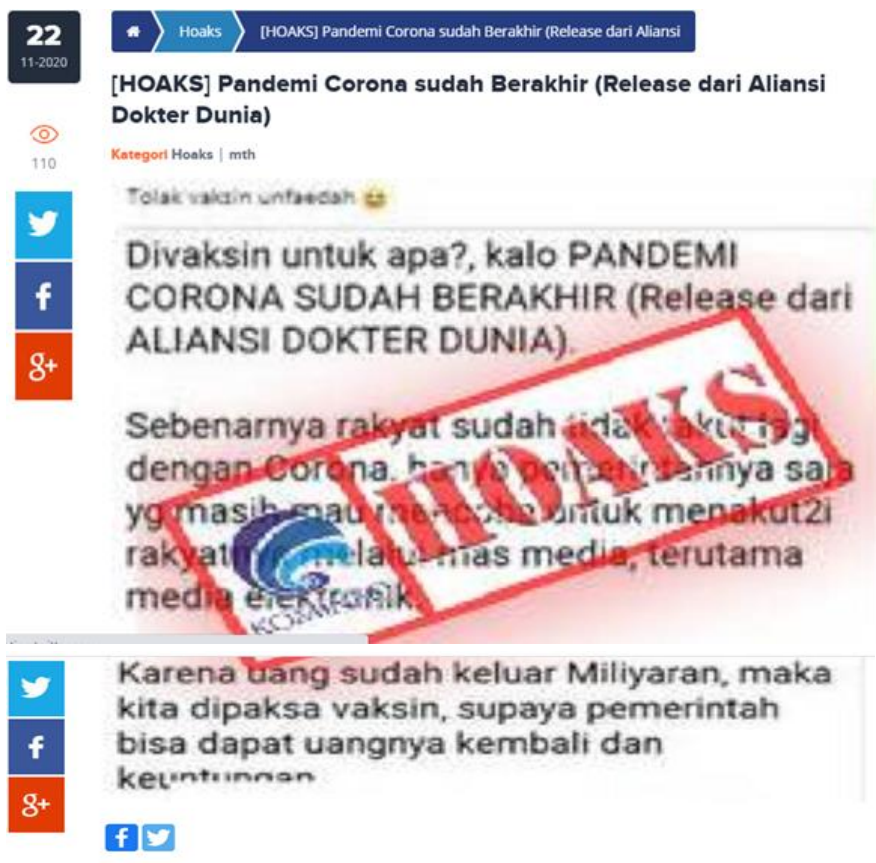

Sumber : (Kominfo,2020) 


\section{Informasi yang beredar :}

Beredar postingan di media sosial Facebook, postingan terkait Vaksin Covid-19 yang tak berguna. Pandemi Corona sudah berakhir dinyatakan oleh aliansi dokter dunia.

Dilansir dari Liputan6.com, klaim bahwa Vaksin Covid-19 tak berguna dan pandemi Virus Corona Covid19 sudah berakhir adalah salah.

\section{Faktanya :}

Hingga Minggu (22/11/2020), masih terjadi penyebaran Virus Corona Covid-19 di seluruh dunia. Melansir data World O Meters, hingga saat ini ada 58.488.517 kasus dan menewaskan 1.386.334 orang dari 220 negara. Khusus di Indonesia melansir data dari covid-19.go.id, ada 493.308 kasus positif dan menewaskan 15.774 orang. Prof. Hindra Irawan Satiri, SpA(K), MTropPaed, Ketua Komnas Kejadian Ikutan Pasca Imunisasi (KIPI) menyampaikan mitos yang mengatakan Vaksin mengandung zat berbahaya adalah tidak benar, karena tentu saja kandungan Vaksin sudah diuji sejak pra klinik.

\section{Link Counter:}

https://www.liputan6.com/cek-fakta/read/4414682/cek-fakta-tidak-benar-vaksincovid-19-unfaedah-karena-pandemi-sudah-berakhir

Ketiga : Misinformasi. Adalah Informasi salah yang disebarkan oleh orang yang mempercayainya sebagai hal yang benar. Contoh air kelapa dapat menyembuhkan COVID 19. 
1) Air kelapa dapat menyembuhkan covid

\begin{tabular}{|c|c|}
\hline Mafindo 0 & \\
\hline & 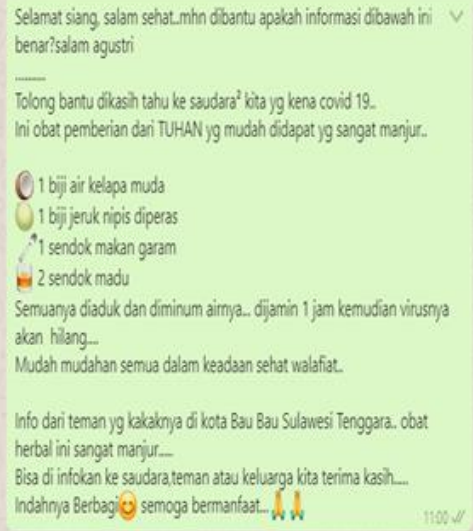 \\
\hline
\end{tabular}

\section{Q. Mafindo 0}

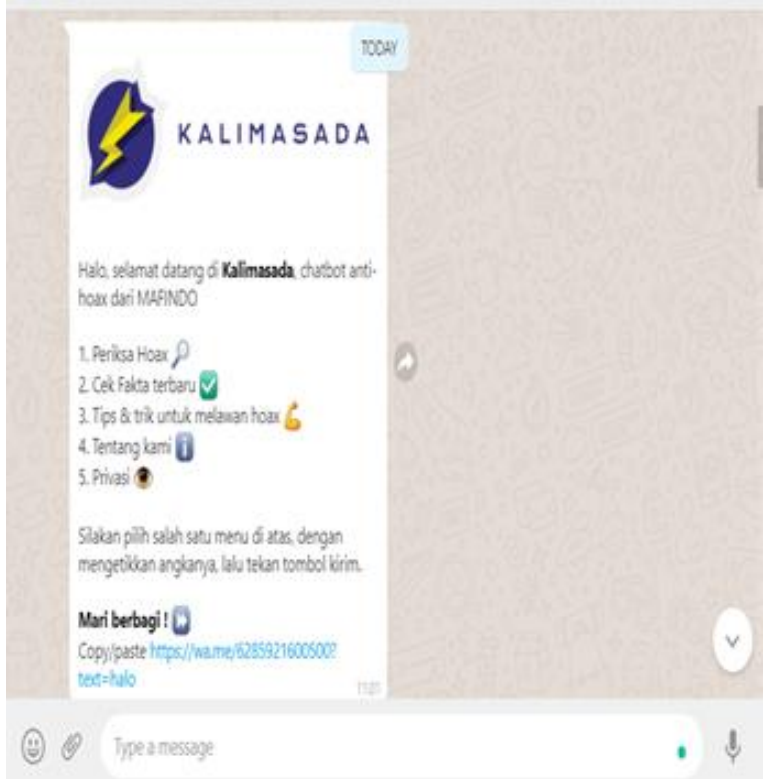

Sumber : (Triyono,2020) 

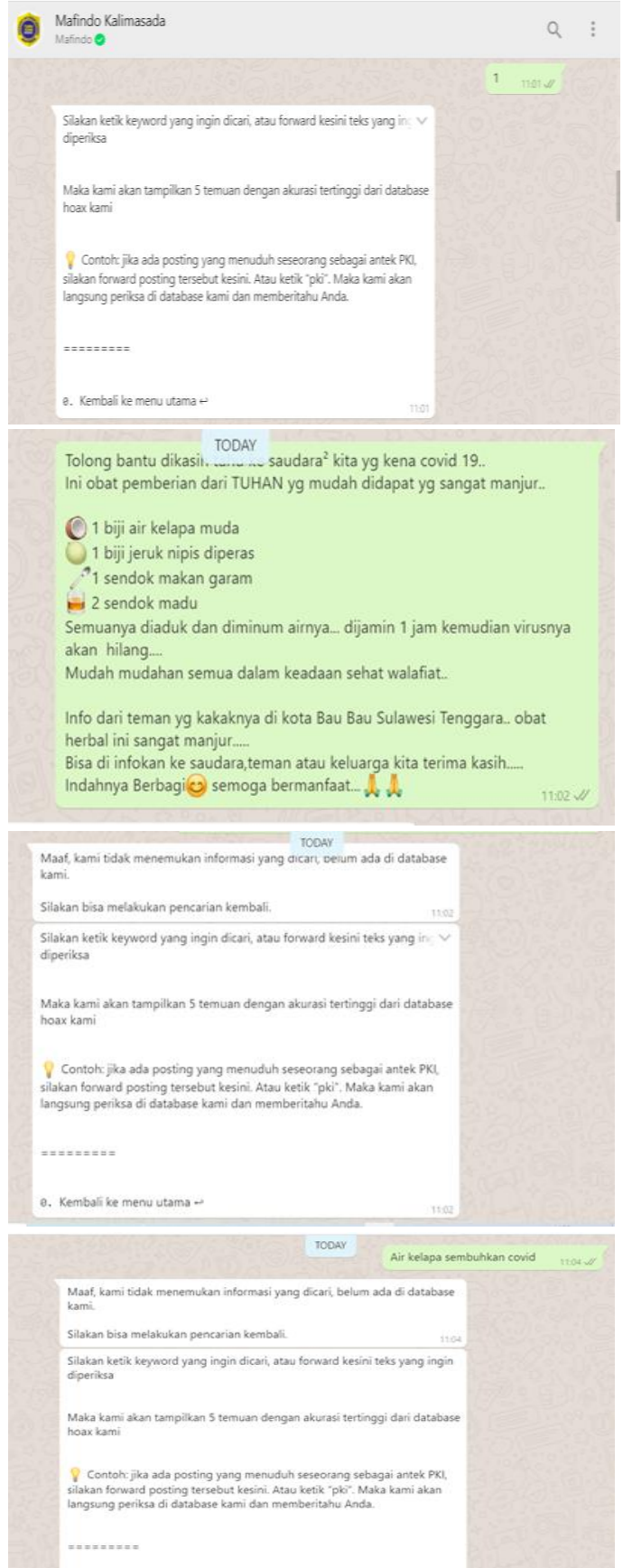

Sumber : (Triyono,2020) 
Temuan 1 dari 2: [SALAH] Campuran Air Kelapa Muda, Jeruk Nipis, dan Garam Dapat Mematikan Virus Corona

Status

Misleading Content

\section{Fakta}

Akun Facebook Ita Yurita menqunggah narasi yang menginformasikan bahwa campuran air kelapa, air perasan jeruk nipis, dan garam dapat menghilangkan virus Covid-19 dalam waktu 1 jam setelah diminum.

Berdasarkan hasil penelusuran, informasi pada unggahan tersebut tidak benar. Dikutip dari portal Liputan6, Farmakolog Universitas Gadjah Mada (UGM) Prof. Dr. Zullies Ikawati, Apt mengatakan kabar tersebut belum terbukti secara klinis, sehingga masyarakat diminta untuk tidak mudah menerima informasi yang belum terbukti itu.

"Jika ada kabar-kabar begitu saja yang belum ada buktinya, sebaiknya tidak langsung diterima," kata Zul... Read more

Mafindo 0

Q

"Jika ada kabar-kabar begitu saja yang belum ada buktinya, sebaiknya tidak langsung diterima;" kata Zullies saat berbincang dengan Liputan6.com.

Guru Besar Fakultas Farmasi UGM tersebut mengungkapkan, menemukan obat Covid-19 itu bukan hal yang mudah, harus dilakukan penelitian mendalam untuk membuktikannya.

"Jika kebetulan saja sembuh ketika minum air kelapa, ya mungkin saja. tetapi, apakah bisa lebih cepat sembuh dari pada yang tidak minum? apakah sudah ada buktinya?," tutur Zulies.

Menurut Zullies, untuk memastikan efek suatu terapi atau obat tentu harus ada disainnya dan ada pembandingnya. Jika hanya sekelompok orang yang minum air kelapa bisa sembuh, apakah sekelompok orang lain yang papar Zullies.

Sebagai tambahan, Epidemiolog sekaligus Juru Bicara Satgas Covid-19 RS UNS, Tonang Dwi Ardyanto, mengatakan campuran air kelapa muda, jeruk nipis, dan garam dapat membuat tubuh kita kuat melawan virus. "Namun, dia bukan obat Campuran minuman itu bukan obat yang secara spesifik berguna untuk melawan suatu penyakit," kata Tonang kepada tim Cek Fakta Kompas.

la menjelaskan air kelapa muda, perasan jeruk nipis, dan garam memilikj manfaat baik bagi kesehatan tubuh, pun bila dikonsumsi terpisah Air kelapa muda sudah lama dikenal sebagai sumber anti-oksidan yang bermanffat menjaga fungsi-fungsi tubuh dalam posisi seimbang. Utamanya, pasokan energi dan keseimbangan elektrolit Air kelapa muda juga mengandung khasiat sebagai antidotum (anti-racun) untuk menetralisir racun. Sementara jeruk nipis dapat menurunkan kolesterol dan garam yang dikonsumsi dalam ukuran yang cukup dapat menjadi nutrisi yang baik bagi tubuh.

Dengan demikian, unggahan akun Facebook ita Yurita dapat dikategorikan sebagai Konten yang Menvesatkan karena belum terbuki secara ilmiah bahwa campuran air kelapa air perasan jeruk nipis, dan garam dapat menghilangkan virus Covid-19 dalam waktu 1 jam setelah diminum.

Selengkapnya dapat dilhat melalui link

hittps///alimasadatumbackhoaxid/focus/4932

\section{Sumber : (Triyono,2020)}


Temuan 2 dari 2: [SALAH] Air Kelapa Muda, Jeruk Nipis, dan Garam Obat Covid-19

Status

Misleading Content

Fakta

Berdasarkan hasil penelusuran, diketahui bahwa klaim tersebut keliru.

Dilansir dari liputan6 com, Farmakolog Universitas Gadiah Mada (UGM) Prof. Dr. Zullies lkawati, Apt, mengatakan bahwa kabar tersebut belum terbukti secara klinis, sehingga masyarakat diminta untuk tidak mudah menerima informasi yang belum terbukti secara klinis.

-Jika ada kabar-kabar begitu saja yang belum ada buktinya, sebaiknya tidak langsung diterima," kata Zullies.

Guru Besar Fakultas Farmasi UGM tersebut mengungkapkan, menemukan obat covid itu bukan hal yang mudah, harus dilakukan penelitian mendalam untuk membuktikannya

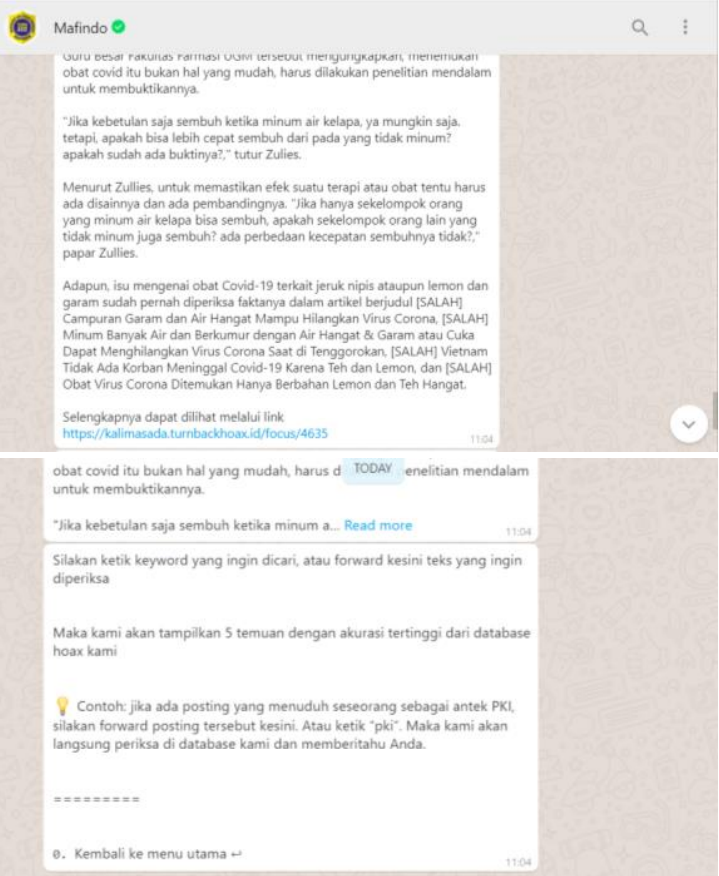

Sumber : (Triyono,2020) 
2) Teh sembuhkan Covid

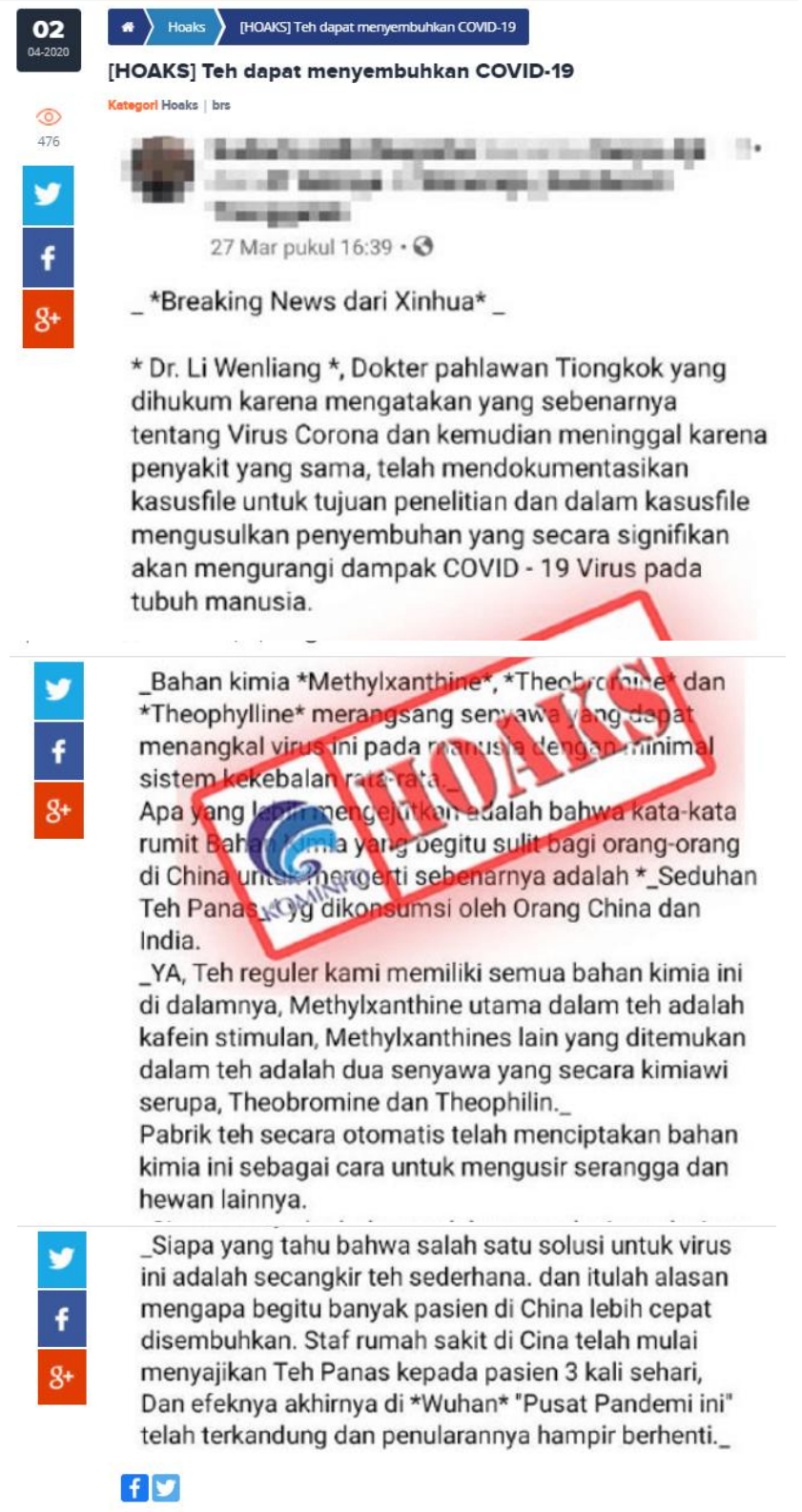




\section{Informasi yang beredar :}

Beredar sebuah informasi di media sosial mengenai kandungan teh dapat menyembuh-kan COVID-19. Dalam pesan tersebut menyebutkan nama seorang Dokter asal Tiongkok bernama Li Wenliang. Dalam pesan itu juga disebutkan rumah sakit di China menyajikan teh kepada pasien tiga kali sehari.

\section{Faktanya :}

Setelah ditelusuri, dr. Li Weliang memang benar seorang dokter di China yang bekerja di rumah sakit Wuhan. Namun, tidak ada satupun artikel yang menyebutkan bahwa dr. Li Weliang mengatakan senyawa kimia di dalam teh dapat melawan virus penyebab COVID-19. Direktur Institut Penelitian Medis Sri Lanka dr. Jayaruwan Bandara mengatakan bahwa teh mungkin dapat meningkatkan imunitas tetapi tidak ada penelitian tentang manfaat meminum teh bagi pasien COVID-19.

Link Counter :

https:/Www.antaranews.com/berita/1394318/cek-fakta-teh-dapat-enyembuhkan-

covid-19-benarkah

https://cekfakta.tempo.co/fakta/702/fakta-atau-hoaks-benarkah-dokter-li-enliang-

dan-rs-di-cina-sarankan-minum-teh-bagi-pasien-corona

https://turnbackhoak.id/2020/03/28/salah-salah-satu-solusi-untuk-virus-ini-

adalah-secangkir-teh-sederhana/ 
3) Banyak pedagang pasar gede positif corona

24

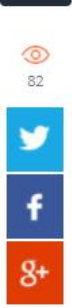

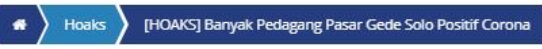

[HOAKS] Banyak Pedagang Pasar Gede Solo Positif Corona

Katogorl Hooks | mth

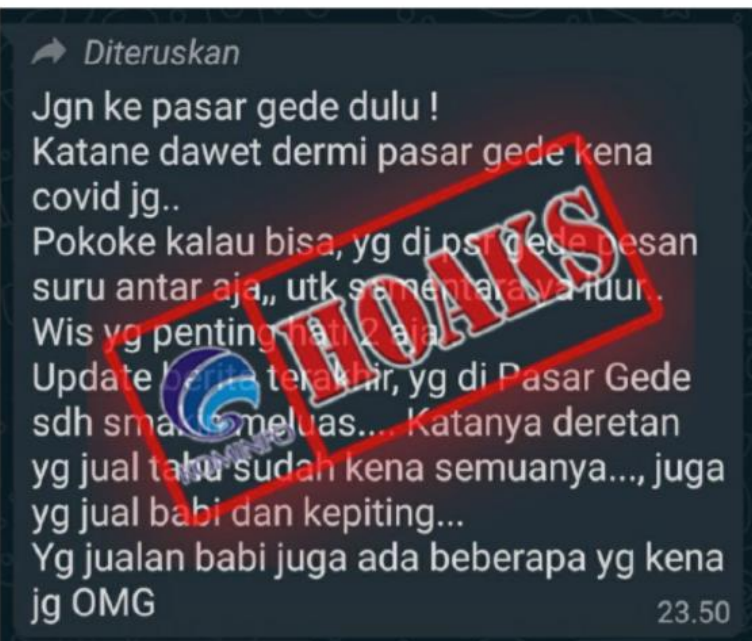

Sumber : (Kominfo,2020)

\section{Informasi yang beredar :}

Beredar sebuah pesan berantai di aplikasi perpesanan WhatsApp yang berisi informasi sejumlah pedagang di Pasar Gede Solo terkonfirmasi positif Covid-19. Kabar tersebut bahkan mencatut pemilik es dawet langganan Presiden Joko Widodo (Jokowi), bu Dermi.

\section{Faktanya :}

Kabar tersebut langsung ditepis oleh Kepala Dinas Perdagangan Kota Solo, Heru Sunardi menegaskan bahwa kabar tersebut tidak benar alias hoaks. Heru mengungkapkan, mencuatnya kabar hoaks tersebut mempengaruhi aktivitas transaksi jual beli di Pasar Gede. Pengunjung yang datang ke Pasar Gede menurun dibandingkan hari-hari sebelum mencuatnya kabar itu. 


\section{Link Counter:}

https://solo.tribunnews.com/amp/2020/11/23/awas-hoaks-banyak-pedagangpasar-gede-solo-positif-corona-bakul-dawet-langganan-jokowi-kenacatut?page $=$ all

https://m.rri.co.id/daerah/934211/hoak-pasar-gede-solo-lockdown-beginisebenarnya

\section{Implementasi Solusi Pemecahan Masalah}

Untuk mendukung pemecahan masalah penelitian tersebut, penulis memberikan pemahaman dan interaksi komunikasi pada khalayak masyarakat. Diantaranya adalah dengan beberapa hal :

\section{a. Melalui Pemahaman Komunikasi efektif}

Munculnya berbagai informasi yang menyebabkan kebingungan masyarakat dibutuhkan solusi agar tidak menimbulkan efek yang lebih luas. Salah satunya adalah dengan memahami makna komunikasi dengan sebaikbaiknya. Komunikasi memiliki unsur-unsur yang dapat membantu melakukan cek and ricek atas beredarnya informasi. Salah satu model komunikasi yang dapat menjadi rujukan adalah model Laswell.

Model ini berorientasi pada beberapa pertanyaan dengan melihat "unsur-unsur" sebagai berikut ; Who,says what, in with channel, to whom, with what effect.

Unsur Who (siapa) berorientasi pada Sumber informasi (komunikator), yaitu orang baik secara individu maupun kelompok atau institusi yang menyampaikan atau memberikan informasi atau pesan kepada pihak lain. Contohnya adalah individu, kelompok/institusi. 
Berikutnya adalah unsur Says What (apa yang dikatakan-pesan). Unsur ini berfokus pada pesan atau informasi yang disampaikan oleh komunikator kepada komunikan.

Unsur Which Channel (media atau saluran), berfokus pada media atau sarana yang digunakan dalam proses komunikasi. Media ini berkaitan dengan seluruh alat (perangkat) yang digunakan dalam proses komunikasi itu. Contohnya: Surat kabar, telepon, majalah, radio, televisi, dan internet (cyber communication).

Unsur selanjutnya To Whom (kepada siapa) / Penerima atau komunikan (receiver) pesan. Unsur ini berkaitan dengan siapa yang akan menerima pesan ini, baik secara personal maupun dalam kelompok besar (large). Contohnya pendengar radio, pembaca surat kabar, pemirsa televisi dan yang lain.

Audien dalam hal ini juga memiliki sifat heterogen. Artinya ada kemajemukan lapisan masyarakat. Ada golongan (status) tertentu, tetapi ada juga ada lapisan masyarakat dalam status yang lainnya. Contohnya semua lapisan dan golongan. Selain hal tersebut, memiliki sifat nonim. Artinya audiens tidak saling mengenal satu sama lain. Unsur berikutnya With What Effect (akibat yang terjadi). Unsur ini mengedepankan pada respons audiens atau khalayak sebagai akibat dari pesan yang disampaikan oleh komunikator. Respon dimaksud adalah perubahan perilaku komunikan. Komunikasi ini akan berhasil jika aktivitas komunikasi itu menimbulkan perubahan perilaku. 
Contohnya sosialisasi bantuan sosial yang tepat sasaran. Bagaimana penerapan komunikasi itu dilakukan dalam memahami maraknya informasi yang berkembang tanpa kendali. Komunikasi dapat diterapkan dalam lingkup dan berbagai momentum seperti Focus Group Discussion (FGD), Ceramah, kuliah, komunitas, kelompok-kelompok, organisasi, tokoh agama, PKK, karangtaruna dll.

\section{b. Melalui pemahanan Berpikir Kritis}

\section{1) Rasional}

Rasional adalah bagaimana berpikir dengan logika alam pikiran yang sehat. Disertai dengan nalar yang masuk akal dan dapat diterima dengan akal sehat. Melubernya informasi membuat logika berpikir menjadi berjalan bahkan terus terasah. Setiap informasi yang didapat setidaknya memerlukan pemikiran dan pemahaman, sehingga ada proses pola berpikir akan dijadikan apa informasi itu. Proses berpikir kritis akan menjawab berbagai pertanyaan rasional. Apa informasi yang dimaksudkan? Kapan dan dimana informasi itu didapat? Mengapa hal itu bisa terjadi? Dan bagaimana peristiwa itu bisa terjadi. Pertanyaan-pertanyaan itu bisa digambarkan dalam formula $5 \mathrm{~W}+1 \mathrm{H}$.

Pertanyaan berikutnya adalah mengapa harus rasional? Untuk menjawab pertanyaan itu tentu harus mampu memaknai pesan yang yang terkandung dalam informasi tersebut. Jika informasi telah mengalami proses rasionalisasi dlam alam pikiran dan nalar, baru akan dikemanakan informasi itu adalah hak setiap orang. Tetapi terpenting adalah informasi itu sudah masuk dalam tataran rasional. 
Bagaimana pola rasional itu bisa dijalankan? Untuk menjalankan pola rasionalisasi dibutuhkan pemahaman dan kemampuan diri dalam mencerna sebuah informasi. Tingkat pengetahuan dan wawasan secara personal menjadi sangat penting dalam membentuk tingkatan rasionalisasi seseorang. Semakin tinggi tingkat rasional seseorang akan sangat kritis terhadap informasi yang diterimanya. Terlebih layak dan tidaknya informasi itu untuk dibagikan kepada orang lain.

Bagaimana solusinya ? mengapa solusi itu diambil? Solusinya adalah dengan menelaah secara menyeluruh atau komprehensif atas informasi yang diterimanya. Memahami betul informasi itu dengan baik dan benar. Saring dulu kebenarannya, bermanfaat atau tidak, mendidik atau tidak, memiliki value atau tidak, dan lain sebagainya.

Solusi berikutnya adalah melakukan proses pemilahan dan pemilihan untuk berbagi informasi jika diperlukan. Kalau memberi manfaat pada kelompok-kelompok tertentu, organisasi, grup dan yang lain ada baiknya dibagikan. Namun, jika dianggap tidak perlu baiknya abaikan saja.

\section{2) Terdapat detail dan pola-pola fenomena}

Memahami bagaimana bagaimana pola-pola informasi yang beredar. Dengan cara melihat detail bahasa yang digunakan (naskah atau tulisan/ redaksinya), atau dialektika dalam audio video. Jika sudah mengetahui segera justifikasi dengan membuat simpulan sementara dan lakukan cek fakat segera mungkin. Bisa dengan sikap kritis dan rasa keinginantahuan yang tinggi dengan menerapkan pola how dan why. 
a) Objektif

Informasi harus diterima seobyektif mungkin dengan melihat pesan yang terkandung di dalamnya. Memahami kata demi kata, kalimat demi kalimat adalah sebuah cara bijak berpikir kritis. Pahami dengan saksama dengan waktu yang relatif tidak lama akan membuahkan hasil yang diharapkan.

b) Mempertimbangkan konsekuensi dan risiko

Tanggungjawab besar dan konsekuensi logis dari membuat dan menyebarkan berita yang belum tentu kebenarannya adalah dampak yang harus diambil. Konsekuensi yang lain adalah membuat masyarakat menjadi curiga dan bahkan membenci kelompok tertentu, bahkan menyusahkan atau bahkan menyakiti secara fisik orang yang tidak bersalah dan memberikan informasi yang salah kepada pembuat kebijaksanaan.(Tular Nalar,2020)

Kabar bohong (hoaks), atau bahkan cuma sekadar iseng mendistribusikan (forward), harap berhati-hati. Ancamannya tidak main-main, bisa kena pidana penjara enam tahun dan denda Rp.1 miliar. Pelaku penyebar hoaks bisa terancam Pasal 28 ayat 1 Undang-Undang Informasi dan Transaksi Elektronik atau Undang-Undang ITE.

Kutipan dalam pasal tersebut berbunyi, "Setiap orang yang dengan sengaja \& atau tanpa hak menyebarkan berita bohong dan menyesatkan, ancamannya bisa terkena pidana maksimal enam tahun dan denda maksimal Rp 1 miliar". Selain Pasal 28 ayat 1 UU ITE, penyebar berita hoaks yang tidak lengkap terancam dapat dikenakan 
sanksi pidana sesuai pasal 14 dan 15 UU No. 1 Tahun 1946 tentang Peraturan Hukum Pidana. Jika menggunakan pasal 14 dan 15 UU 1/1946, tidak tanggung-tanggung ada yang bisa dikenakan sanksi 2 tahun, 3 tahun bahkan 10 tahun yang dikualifikasi dalam 3 bentuk pelanggaran,yakni:

\begin{tabular}{|l|l|l|l|}
\hline No & Kualifikasi Konten Hoaks & \multicolumn{1}{|c|}{ Sanksi } & Dasar Hukum \\
\hline 01 & $\begin{array}{l}\text { Menyiarkan berita bohong } \\
\text { dengan sengaja menerbitkan } \\
\text { keonaran di kalangan rakyat }\end{array}$ & Tahun & Pasal 14 ayat (1) \\
\hline 02 & $\begin{array}{l}\text { Menyiarkan suatu berita atau } \\
\text { mengeluarkan pemberitahuan } \\
\text { yang dapat menerbitkan } \\
\text { keonaran dikalangan rakyat, } \\
\text { sedangkan ia patut dapat } \\
\text { menyangka bahwa berita atau } \\
\text { pemberitahuan itu adalah } \\
\text { bohong, dihukum dengan } \\
\text { penjara setinggi-tingginya } \\
\text { tiga tahun. }\end{array}$ & $\begin{array}{l}\text { Pasal 14 ayat (2) } \\
\text { Menyiarkan kabar yang tidak } \\
\text { pasti atau kabar yang } \\
\text { berlebihan atau tidak lengkap, } \\
\text { sedangkan ia mengerti dan } \\
\text { mampu menduga bahwa } \\
\text { kabar itu akan menerbitkan } \\
\text { keonaran }\end{array}$ & \\
\hline
\end{tabular}

Pasal 14 dan 15 UU 1/1946 itu lebih mudah dikenakan terhadap penyebar berita hoaks ketimbang menggunakan pasal-pasal dalam UU ITE. Karena pasal penyebaran berita hoaks yang diatur dalam UU ITE sangatlah terbatas pada konteks yang dapat menimbulkan kerugian konsumen dan ada juga yang sifatnya ujaran kebencian yang menimbulkan permusuhan sara.

Ada 3 jenis konten hoak yang dapat dipidana penjara 4-6 tahun dan dengan denda maksimal Rp750 juta hingga Rp. 1 miliar berdasarkan UU No. 19 Tahun 2016 tentang Perubahan Atas UU No. 11 Tahun 2008 tentang Informasi dan Transaksi Elektronik (ITE), yakni: 


\begin{tabular}{|l|l|l|}
\hline No & Muatan Konten & Dasar Hukum \\
\hline 01 & $\begin{array}{l}\text { Pencemaran nama baik atau } \\
\text { fitnah }\end{array}$ & Pasal 27 ayat (3) \\
\hline 02 & $\begin{array}{l}\text { Penipuan untuk motif } \\
\text { ekonomi yang merugikan } \\
\text { konsumen }\end{array}$ & Pasal 28 ayat (1) UU ITE \\
\hline 03 & Provokasi terkait SARA & Pasal 28 ayat (2) UU ITE \\
\hline
\end{tabular}

Sementara itu, jika dilakukan oleh terhadap oknum pelaku Aparatur Sipil Negara (ASN) meliputi sanksi ringan dan sanksi berat sebagaimana diatur dalam pasal 7 PP No. 53 Tahun 2010 tentang Disiplin Pegawai Negeri Sipil.

Tak tanggung-tanggung, bukan hanya sekadar oknum ASN yang menyebarkan konten hoaks bermuatan ujaran kebencian, bahkan ASN yang memperlihat persetujuan pendapat dengan melakukan like, dislike atau berkomentar pada postingan yang bermuatan ujaran kebencian tersebut juga dapat dikenakan sanksi ringan.

c) Tidak terbatas kepada satu keterampilan saja

Untuk dapat memahami pentingnya literasi digital memiliki perspektif yang sangat luas. Tidak terbatas pada salah satu bidang ilmu saja, tetapi bisa dengan latar belakang ilmu yang lain karena memang sifatnya yang fleksibel. Begitu juga dengan skill atau kemampuan dalam memberikan edukasi pada masyarakat. Dengan banyaknya ketrampilan atau skill yang dimiliki masingmasing personal akan semakin mendukung pemecahan masalah-masalah yang dihadapi terkait dengan kurangnya optimalisasi literasi digital. Ketrampilan tersebut dapat berupa kemampuan dalam bidang teknologi informasi, komunikasi, manajemen dan lainnya. 
c. Literasi digital dengan pola 38 (3 level, 8 Kompetensi)

Metode ini adalah melakukan sosialisasi dan literasi pada berbagai kelompok, organisasi masyarakat dalam mengoptimalkan pengetahuannya tentang literasi digital.

1) 3 Level, diantaranya adalah TAHU, TANGGAP DAN TANGGUH

a) TAHU ;

Memiliki kompetensi pribadi sebagai model literasi digital.

- mengakses informasi

- mengelola informasi

b) TANGGAP ;

Mampu merespons situasi dg kapasitas literasi digital yg dimiliki.

- mendesain pesan

- memproses informasi

- berbagi pesan

c) TANGGUH :

Mampu merespon tantangan yg lebih besar, merangkul stake holders

- membangun ketangguhan diri

- perlindungan data

- kolaborasi

2) 8 KOMPETENSI 


\section{1) Mengakses Informasi}

a) Eksplore informasi

Orientasi dari hal ini adalah mengeksplorasi media dan media digital untuk mencari informasi, data, dan konten sesuai dengan kebutuhan. Mengakses memberi arti memanfaatkan seluruh fitur yang tersedia untuk mencari dan mengolah informasi, data, dan konten di lingkungan digital. Artinya mampu menggunakan berbagai fitur yang tersedia dalam beragam platform digital (media sosial, aplikasi percakapan, media online, mesin pencari, dan lain- lain) yang digunakan untuk mengakses informasi, data, dan konten sesuai dengan kebutuhan.

Hal lain yang mendukung adalah mampu mencari informasi, data, dan konten dalam beragam platform digital (media sosial, aplikasi percakapan, media online, mesin pencari, dan lainlain).Selain itu harus mampu membuat rangkuman informasi, data, dan konten dalam beragam platform digital (media sosial, aplikasi percakapan, media online, mesin pencari, dan lainlain).

Berikutnya adalah memiliki peningkatan kemampuan dalam memanfaatkan, membuat daftar, dan merangkum berbagai fitur yang tersedia dalam beragam platform digital (media sosial, aplikasi percakapan, media online, mesin pencari, dan lain- lain) yang digunakan untuk mengakses informasi, data, dan konten sesuai dengan kebutuhan. 
b) Memahami jenis-jenis media sosial

Salah satu media yang menjadi ruang penyebaran informai adalah media sosial. Media ini adalah platform media yang berbasis internet untuk menjalin komunikasi dengan berbagai netizen dari berbagai level dan kelompok sosial. Media ini berkembang pada era ini dengan perkembangan yang sangat cepat. Jumlahnya juga beragam, diantaranya adalah facebook, twitter, whatsapps, youtube. instagram dan lainnya. Masing-masing jenis ini memiliki karakteristik dan kekurangan, kelebihan masing-masing.

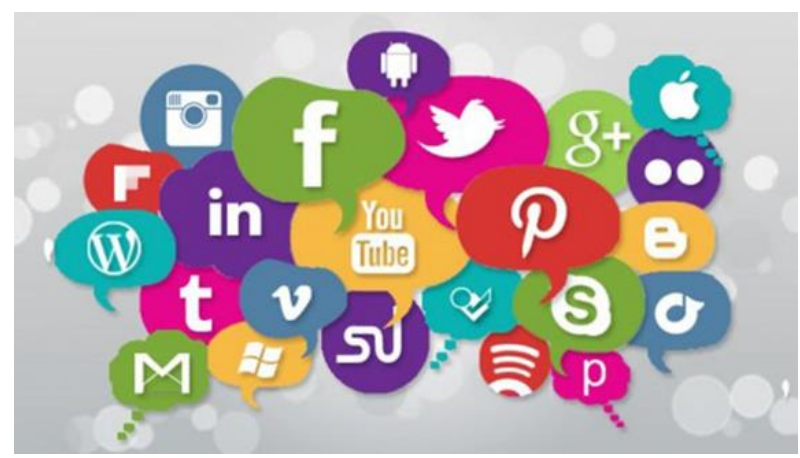

Sumber : https://www.hipwee.com/opini/penyalahgunaan-mediasosial-di-masa-kini/

\section{- Youtube}

Berdasarkan studi dan riset data yang dihimpun oleh We Are Social pada tahun 2019, pengguna media sosial di Indonesia sudah mencapai 150 juta orang. Hal ini dapat diartikan bahwa sekitar $57 \%$ dari seluruh penduduk Indonesia sudah menggunakan berbagai media sosial. 


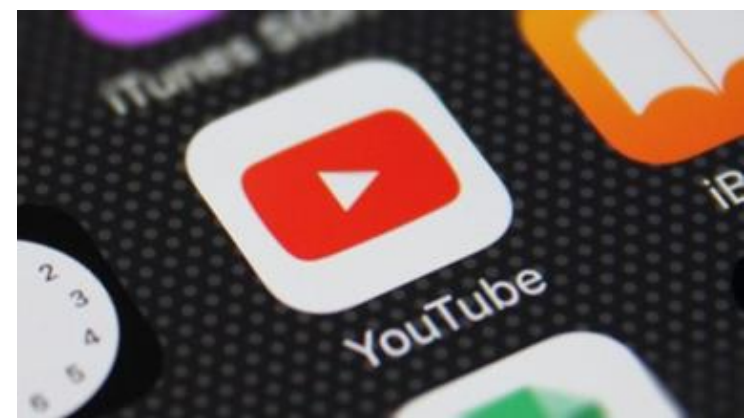

https://techcrunch.com/2020/03/16/youtube-warns-of-increasedvideo-removals-during-covid-19-crisis/

Macam media sosial yang pertama adalah youtube. Youtube sendiri merupakan media sosial yang memungkinkan para penggunanya untuk melihat, mengirim, dan berbagi video.

Berdasarkan data yang dihimpun dari "We Are Social" telah tercatat bahwa 88\% orang Indonesia telah menggunakan media sosial Youtube.

Ini artinya bahwa dari 150 juta pengguna media sosial di Indonesia, sekitar 132 juta orang sudah menggunakan Youtube.

\section{- Whatsapps..}

Pada urutan kedua, jenis media sosial yang paling banyak digunakan oleh orang Indonesia selanjutnya adalah whatsapp. Whatsapp atau yang biasa disebut dengan WA merupakan media sosial chatting tanpa menggunakan biaya, namun cukup menggunakan koneksi internet saja. 


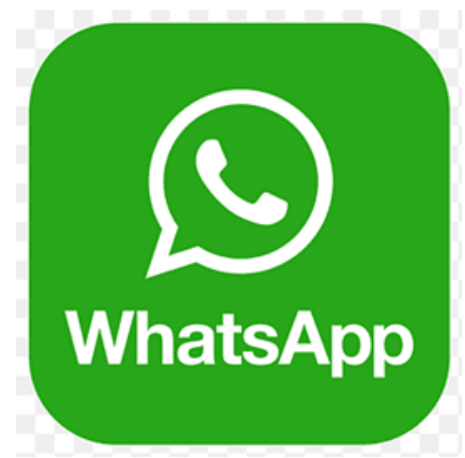

https://www.pngegg.com/en/png-bbxte

Dihimpun dari data "We Are Social", telah tercatat bahwa $83 \%$ orang Indonesia telah menggunakan media sosial whatsapp. Ini artinya, dari 150 juta pengguna media sosial di Indonesia, sekitar 125 juta orang sudah menggunakan WhatsApp.

\section{- Facebook}

Facebook merupakan aplikasi media sosial yang dapat dikatakan lengkap karena kita dapat berkomunikasi dengan orang lain, berbagi video, membuat suatu grup atau perkumpulan, membuat jadwal bersama, dan sebagainya.

\section{facebook.}

https://www businessinsider.com/Aacebook-logo-change-2015-7??=US\& IR=T| 


\section{- Instagram}

Media sosial ini paling sering digunakan oleh orang Indonesia. Jenis ini, orang Indonesia sering menyebutnya dengan singkatan IG atau Instagram yang memungkinkan bagi penggunanya untuk berbagi foto dan video serta membuat cerita singkat pada fitur stories.

Berdasarkan data yang dihimpun "We Are Social", tercatat $80 \%$ orang Indonesia yang menggunakan media sosial Instagram. Ini artinya, dari 150 juta pengguna media sosial di Indonesia, sekitar 120 juta orang sudah menggunakan Instagram.

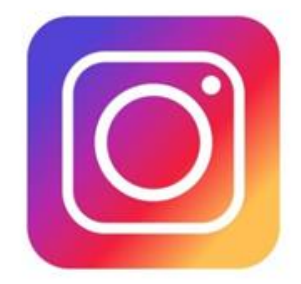

https://www.freepik.com/free-vector/instagram-icon_954290.htm

\section{- Tiktok}

Berikutnya adalah media sosial dengan nama tik tok.Tik tok ternyata masuk dalam 10 besar sosial-media terpopuler saat ini. Aplikasi yang diluncurkan pertama kali pada 2016 dan dikembangkan oleh perusahaan Byte Dance yang bermarkas di China.

Tiktok merupakan layanan jejaring sosial di mana bisa berbagi video berdurasi pendek. Jenis ini bisa menampilkan musik sebagai latar belakang dan dapat diedit seperti dipercepat. 
Bahkan juga diperlambat, ataupun ditambah filter baru.

Sebagai aplikasi yang memiliki jumlah pengguna aktif mencapai lebih dari 500 juta orang. Tik tok tak hanya dapat digunakan untuk membuat video pribadi. Namun juga bisa melakukan duet dengan teman yang kamu pilih untuk membuat video menarik.

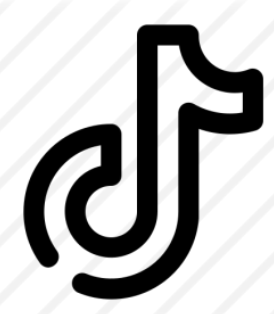

https://www.flaticon.com/premium-icon/tiktok_2594962

- Line

Jenis media sosial berikutnya adalah Line. Media ini merupakan media sosial asli Jepang yang memungkinkan penggunanya untuk berkomunikasi, membuat sebuah grup atau perkumpulan, menyimpan gambar dan video, serta adanya fitur stiker pada aplikasi ini membuat media sosial Line semakin diminati.

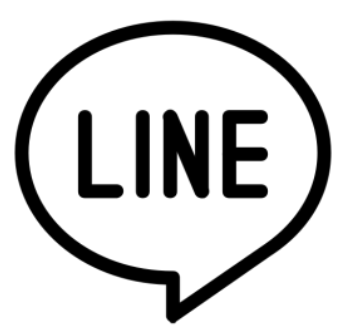

https://www.iconfinder.com/icons/2006469/line_media_network_social_icon| 


\section{- Twitter}

Media berikutnya dan paling sering digunakan oleh orang Indonesia adalah twitter. Twitter merupakan media sosial yang memungkinkan para penggunanya untuk mengirim dan membaca pesan teks hingga 200 karakter ataupun yang lebih sering disebut dengan kicauan atau tweet.

Berdasarkan data yang dihimpun "We Are Social", telah tercatat bahwa $2 \%$ orang Indonesia yang menggunakan media sosial Twitter. Ini artinya, dari 150 juta pengguna media sosial di Indonesia, sekitar 78 juta orang sudah menggunakan Twitter.

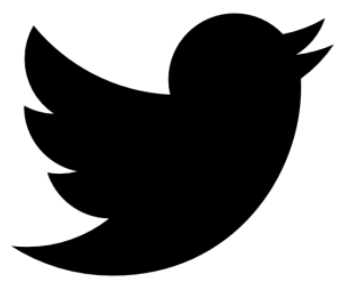

https://www.freepik.com/free-icon/twitter-logo_748853.htm|

\section{c) Mampu mengakses informasi}

(1) Aspek ini memiliki pemahaman bahwa seseorang harus mampu secara benar dalam mengakses media sosial/media digital, mampu melakukan verifikasi informasi yang mereka peroleh dari media sosial/media digital.

(2) Berikutnya adalah mengetahui seluruh fungsi fitur yang ada di media sosial/media digital dan mampu mengoperasikannya.

Memahami fitur-fitur yang terdapat dalam media sosial seperti ;
(a) Fitur Login
(b) Fitur Identitas 
(c) Fitur Posting (status teks, foto, video)

(d) Fitur Berbagi

(e) Fitur Komentar

(3) Memahami fungsi media digital/media sosial adalah antara lain :

(a) untuk mengaktualisasi diri, antara lain :

(b) Untuk berbagi informasi

(c) Untuk mengembangkan hobi

(d) Untuk berkolaborasi

(e) Untuk menambah relasi

(f) Untuk berbisnis

(g) Untuk Pendidikan

\section{d) Mengelola Informasi}

Untuk memahami pentingnya informasi secara utuh wajib mengelola informasi dengan baik. Mengelola informasi mengandung arti mengorganisir, menafsirkan, dan merepresentasikan data. Disamping itu juga, mampu mengambil data, informasi, dan konten dalam lingkungan digital, mengenali data, informasi dan konten yang didapatkan dalam beragam platform digital (media sosial, aplikasi percakapan, media online, mesin pencari, dan lain-lain).

Tidak kalah pentingnya adalah melakukan klasifikasi data, informasi, dan konten yang didapatkan dalam beragam platform digital (media sosial, aplikasi percakapan, media online, mesin pencari, dan lain-lain) sesuai tipe atau format file.

Dalam melakukan pengelolaan informasi ini harus memahami betul tentang informasi yang beredar, dengan melihat beberapa unsur berikut : 
(1) Mengetahui cara untuk mengambil data, informasi, dan konten di media sosial.

(2) Mengetahui ragam mesin pencari yang popular.

(3) Mengetahui cara mencari dan menyaring informasi

(4) Mengetahui cara mengambil informasi berbentuk teks, gambar, dan video

(5) Mengorganisir, menafsirkan, dan merepresentasikan data.

(6) Mampu mengambil data, informasi, dan konten dalam lingkungan digital

\section{(1) Mendesain Pesan}

Dalam mendesain informasi dalam bentuk pesan dapat diimplementasikan dalam bentuk :

(a) Merangsang kreativitas untuk mendesain pesan dengan menggunakan teknologi digital yang beretika.

(b) Mampu memahami berbagai regulasi, kebijakan, dan kode etik untuk mendesain pesan terkait hak cipta.

(c) Menganalisis potensi pelanggaran etika dan regulasi dalam suatu pesan yang beredar di media digital.

(d) mampu menganalisis kasus pelanggaran etika yang terjadi di lingkungan digital.

(e) Peserta Tular Nalar mampu mencatatkan hasil analisisnya dan mempublikasikannya di media digital.

(f) Peningkatan kemampuan pemahaman peserta tentang pelanggaran etika dan regulasi di lingkungan digital. 
(g) Peningkatan kemampuan peserta dalam merancang pesan tanggapan tentang pelanggaran etika di lingkungan digital

Selain itu, harus dapat memahami caracara verifikasi sumber data digital, informasi, dan konten berupa teks, foto, dan video yang ditemukan di media sosial.

\section{Cara verifikasi :}

(a) Mengecek pada sumbernya langsung, klik situs, dan lain-lain

(b) Mengecek pada media massa yang kredibel

(c) Mengecek pada situs pencari fakta, seperti www.turnbackhoak.id, situs www.cekfakta. com

(d) Mengecek pada Kalimasada atau chatbot untuk fungsi sejenis

(e) Kalau sudah tahu, bagaimana? Apakah disimpan sendiri, atau dibagikan pada yang lain? Berbagi informasi melalui berbagai aplikasi, how?

\section{(2) Memproses Informasi}

Memproses Informasi memiliki unsurunsur yang harus diketahui, diantaranya :

(a) Memanfaatkan teknologi digital untuk mengakses, mengelola, dan berbagi konten tata kelola kesehatan publik kasus COVID19.

(b) Mampu memahami berbagai regulasi, kebijakan, dan kode etik untuk memproses informasi tata kelola kesehatan publik kasus COVID-19 
(c) Mampu menganalisis data, informasi dan konten digital tata kelola kesehatan publik kasus COVID-19

(d) Mampu memberikan respons berupa analisis tentang data, informasi, dan konten digital tata kelola kesehatan publik kasus COVID-19.

(e) Mengevaluasi hasil analisis tentang data, informasi, dan konten digital tata kelola kesehatan publik kasus COVID-19

(f) Memberikan respon berupa analisis tentang data, informasi, dan konten digital tata kelola kesehatan publik kasus COVID-19.

(g) Mengevaluasi hasil analisis tentang data, informasi, dan konten digital tata kelola kesehatan publik kasus COVID-19.

\section{(3) Berbagi Pesan}

Berbagi Informasi

(a) Memahami community guidelines yang menjadi aturan dasar berbagai platform berbagi pesan.

(b) Membagikan pesan sesuai dengan community guidelines yang berlaku Mampu menganalisis potensi pelanggaran terhadap community guidelines dari suatu pesan yang ada

(c) Mendeteksi potensi pelanggaran suatu data, informasi, dan konten digital

(d) Mendeteksi potensi pelanggaran suatu data, informasi, dan konten digital mengandung unsur mis/disinformasi. 
(4) Membangun Ketangguhan Diri

Memanfaatkan teknologi untuk mengelola diri dan pembelajaran pribadi, terutama terkait isu intoleransi dan diskriminasi sekaligus keberagaman dan KBB (Kebebasan Beragama dan Berkeyakinan).

Isu ini rentan menimbulkan konflik antar masyarakat walaupun disadari adanya keragaman dan prinsip KBB dan rentan menyerang pribadi dari pihak minoritas.

Berpartisipasi aktif sebagai warga negara dalam lingkungan sekolah maupun eksternal dalam solusi nyata terhadap maraknya informasi tentang intoleransi dan diskriminasi. Melakukan aktivitas diseminasi yang berhubungan dengan keberagaman dan KBB dalam ruang digital

Merefleksikan beragam opini dan komentar netizen di dunia digital ke dalam konten digital dengan isu terkait. Netizen dibagi dalam lingkungan sekolah/Pendidikan dan eksternal.

Mengintegrasikan berbagai isu spesifik dalam keberagaman dan KBB untuk melawan intoleransi dan diskriminasi dalam konten digital

Menyaring opini dan komentar Netizen menjadi masukan untuk membentuk pribadi yang tetap objektif dalam menghadapi informasi intoleransi dan diskriminasi serta kematangan dalam pengetahuan dan sikap membuat lebih bijak dalam berpendapat dan lebih mementingkan sebaran isu keberagaman 
yang memperhatikan kondisi sosial masyarakat lintas agama, dari lingkungan sekolah/ Pendidikan dan eksternal

\section{(5) Perlindungan Data}

(a) Membangun sistem keamanan personal dan orang-orang terdekatnya dalam lingkungan digital terkait informasi intoleransi dan diskriminasi.

(b) Tentang beragam regulasi, kebijakan, dan kode etik untuk menjaga keamanan data, termasuk kebijakan privasi

(c) Melindungi data dan privasi pihak lain dalam lingkungan digital, terutama yang berkaitan dengan perilaku intoleransi dan diskriminasi mempertimbangkan tingkat kerawanannya

(d) Mengevaluasi dan ancaman kepada perlindungan data dan privasi diri dalam lingkungan digital seperti media sosial.serta memasang peralatan relevan untuk perlindungan

(e) Mengevaluasi dan instalasi alat-alat untuk proteksi data serta bagaimana mempromosikan ke jaringan yang lebih luas

\section{(6) Kolaborasi}

(a) Bekerja sama dengan teman sebaya dalam lingkungan sekolah atau eksternal maupun pihak lain melalui teknologi digital terkait promosi isu keberagaman dan KBB (Kebebasan Beragama dan Berkeyakinan) dan memfilter informasi tentang diskriminasi dan intoleran.

(b) Berjejaring dengan teman teman sebaya atau pihak lain dalam lingkungan sekolah atau eksternal atau pihak lain untuk 
mengkonstruksi dan memproduksi sumber daya serta pengetahuan bersama.mengenai isu intoleransi dan diskriminasi.

(c) Menggunakan jejaring digital eksternal sekolah dan Pendidikan untuk memperluas aktivitas secara luring

(d) Mengevaluasi konten digital dalam jejaring yang berbeda dan membuat jaringan dalam berbagai platform media sosial, situs, grup chat, dll.

(e) Melibatkan teman teman sebaya dalam lingkungan Pendidikan/sekolah serta eksternal

(f) Memanfaatkan fitur (dalam platform media sosial, situs, grup chat) digital untuk memproduksi konten (podcast, menulis, blogging, YouTube, dll) untuk lebih mendorong isu keberagaman dan KBB untuk teman teman sebaya sekolah dan lingkungan Pendidikan dalam jangka Panjang

\section{Dalam kolaborasi harus memahami hal-hal berikut :}

(a) Bentuk-bentuk kolaborasi, apa saja? Kolaborasi daring, kolaborasi luring

(b) Mengenal 'crowd' sebagai bentuk kolaborasi: crowdfunding, crowdsourcing, crowdsharing.

(c) Membangun kolaborasi secara daring, bagaimana caranya?

(d) Unsur kolaborasi daring: tema, platform, admin, member, aturan, mekanisme kolaborasi. 


\section{BAB VII KESIMPULAN}

Dari hal tersebut di atas dapat kita berikan kesimpulan dalam menjawab beberapa pertanyaan, diantaranya ;Bagaimana hoak pada masa pandemi ini berkembang dalam media ? Bagaimana hoak dapat mempengaruhi kehidupan masyarakat? Bagaimana perilaku masyarakat dalam menerima informasi hoak?

Pertanyaan-pertanyaan tersebut dapat dijawab dan disimpilkan dalam sebuah proses komunikasi yang meliputi :

\section{A. Memahami Pola Pikir}

Merebaknya hoaknya ini menjadi sejarah baru dalam perkembangan informasi di negeri ini. Bidang kesehatan seperti wabah COVID19 berkontribusi besar bagi perkembangan infodemik. Dalam bidang yang lain juga memiliki dampak yang besar bagi masyarakat. Munculnya hoak memberi ruang bagi semua orang untuk berperilaku dengan menyebarkan informasi seperti tanpa kendali. Solusiny adalah dengan mengembangkan ;

1. Pola berpikir kritis dengan mengembangkan pola $3 \mathrm{~T}$. Tahu, Tanggap dan Tangguh. Ketiga aspek ini memiliki komponen yang ideal dalam menjaga informasi dapat dipertanggungjawabkan. Selain itu mampu memperkuat informasi dapat discreening dalam berbagai tahap, sehingga informasi yang diterima masyarakat benar-benar tanpa dihiasi dengan hoak. Oleh karenanya diperlukan pengetahuan dan wawasan yang cukup dalam memahami merebaknya informasi. Cara nya adalah dengan memahami unsur-unsur yang diperlukan.

a. Unsur kognitif melaui Digital Literacy

Memahami berbagai upaya dan strategi dalam memberikan edukasi tentang hoak atau literasi digital. 
Literasi digital merupakan Keterampilan melek media menyajikan kerangka kerja untuk mengakses, menganalisis, mengevaluasi dan membuat pesan dalam berbagai bentuk, membangun pemahaman tentang peran media dalam masyarakat, serta mengembangkan keterampilan pentingan dalam penyelidikan dan ekspresi diri(Tamburaka, 2013: 13).

b. Mengembangkan Digital Civility

Konsep ini adalah bagaimana Saling Melindungi Pengguna internet harus dapat menunjukkan rasa hormat terhadap kebiasaan orang lain dalam dan protektif terhadap hak orang lain dan terhadap haknya sendiri. Pengguna internet juga harus dapat mengaplikasikan keterampilan untuk bersifat etis dan dalam batasbatas norma sosial. Secara kontinyu membaca berita / mengakses berita dari media yang kredibel atau well-established dan dihormati.

Mayoritas orang yang paling rentan terhadap hoaks adalah orang yang jarang mengonsumsi berita dari sumber yang terpercaya. Oleh karenanya perlu mengetahui sumber-sumber berita yang terpercaya tersebut. Kalau suatu berita kedengarannya tidak mungkin, bacalah dengan lebih teliti karena seringkali itu karena memang itu tidak mungkin. Jangan share artikel/foto/pesan berantai tanpa membaca sepenuhnya dan yakin akan kebenarannya.

c. Memahami ciri-ciri berita hoak :

1) Didistribusikan via email atau media sosial karena efeknya lebih besar.

2) Berisi pesan yang membuat cemas, panik para pembacanya.

3) Diakhiri dengan himbauan agar si pembaca segera memforwardkan warning tersebut ke forum yang lebih luas. Hoak memanfaatkan iktikad baik si 
pembaca, sehingga pembaca ini tanpa meneliti terlebih dahulu kebenaran beritanya, langsung segera menyebarkannya ke forum yang lebih luas. Akibarnya lalu lintas peredaran data di internet makin padat dengan berita yang tidak benar.

4) Biasanya pengirim awal hoak ini tidak diketahui identitasnya.

\section{KONTEN NEGATIF DIGITAL}

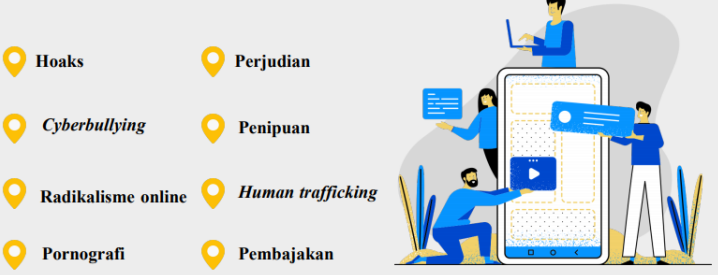

d. Memahami unsur Tools / alat yang sudah tersedia

Tools adalah alat terakhir yang kita gunakan dalam memahami informasi yang meragukan atau cenderung hoak.Caranya adalah menggunakan berbagai alat yang ada di lingkungan kita. Seperti

1) Cekfakta.com

2) Kalimasada chat bot

3) Turnbackhoax.id, dan lainnya

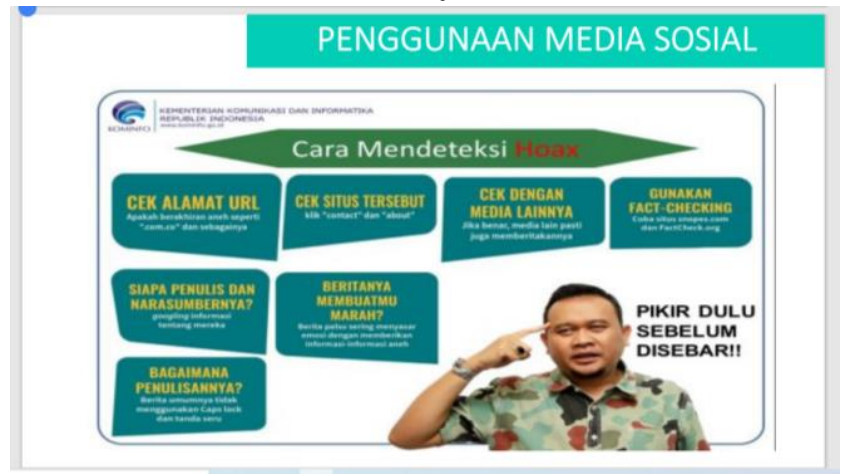

Gambar-gambar macam cek fakta (Kominfo,2020) 


\section{B. Memahami sumber dan Pengaruh Hoak}

Hoaks / fake news bukan sesuatu yang baru, dan sudah banyak beredar sejak Johannes Gutenberg menciptakan mesin cetak pada tahun 1439. Sebelum zaman internet, "hoaks" bahkan lebih berbahaya dari sekarang karena sulit untuk diverifikasi. Hoaks sendiri terbagi atas beberapa jenis, yaitu :

1. Hoaks proper

Hoaks dalam definisi termurninya adalah berita bohong yang dibuat secara sengaja. Pembuatnya tahu bahwa berita itu bohong dan bermaksud untuk menipu orang dengan beritanya.

2. Judul heboh tapi berbeda dengan isi berita.

Kebiasaan buruk banyak netizen adalah hanya membaca headline berita tanpa membaca isinya. Banyak beredar artikel yang isinya benar tapi diberi judul yang heboh dan provokatif yang sebenarnya tidak sama dengan isi artikelnya.

3. Berita benar dalam konteks menyesatkan

Kadang-kadang berita benar yang sudah lama diterbitkan bisa beredar lagi di media sosial. Ini membuat kesan bahwa berita itu baru terjadi dan bisa menyesatkan orang yang tidak mengecek kembali tanggalnya.

Berita bohong atau hoaks ternyata bukan sekadar informasi saja. Di tangan sekelompok orang, hoaks bisa menjadi ladang bisnis yang menguntungkan. Seperti yang dilakukan tim Saracen. Saracen adalah kelompok pembuat berita hoaks yang bekerja secara profesional dan memiliki ribuan akun dalam menjalankan aksinya. Kelompok ini mempunyai struktur organisasi yang sangat rapi. Mereka sudah menjalankan aksinya sejak November 2015. Cara kerjanya, mereka menawarkan kepada siapa saja yang membutuhkan sebaran hoaks. 
Bisnis berita hoaks tentu sangat meresahkan masyarakat. Dengan beredarnya berita hoaks, masyarakat bisa kebingungan mana informasi yang bisa dipercaya. Kelompok mereka beraksi melalu media sosial seperti Facebook. Mereka membuat grup berita atau media online dengan bantuan akun palsu dan jaringan admin mereka yang aktif.

Berita hoaks semakin terorganisir dan profesional. Dampak dari hoaks ini bisa melebar ke manamana. Dengan pundi-pundi uang yang mengalir, kelompok ini akan melakukan apa saja agar berita hoaks semakin viral.

Pengaruh yang diakibatkan dari ulah kelompok yang menjadikan berita hoaks sebagai bisnis:

1. Generasi Muda Bisa Tersita Waktunya.

Mayoritas anak muda terutama remaja atau mahasiswa menilai kebenaran berita dari detail konten seperti jumlah dan besarnya foto, panjang artikel, dan lainlain. Hal ini menjadi alasan kenapa anak muda sangat rentang sekali dengan berita hoaks. Berita hoaks di media sosial bisa berdampak buruk bagi generasi muda. Produktivitas anak muda bisa tersita karena seringnya menggunakan media sosial.

2. Memicu Perpecahan

Berita hoaks seringkali bermuatan isu SARA. Kelompok contoh Saracen juga bermain di tema ini. Mereka bisa menyebarkan konten-konten bernada SARA. Akibatnya, masyarakat akan terpecah belah karenanya. Masyarakat tidak bisa membedakan isu mana yang benar dan hoaks. Oleh karenanya tidak boleh dan mudah goyah hanya karena provokasi dan hasutan.

3. Menurunkan Reputasi Pihak yang Dirugikan.

Berita hoaks seringkali menjatuhkan pihak tertentu. Dengan banyaknya berita hoaks, pihak yang dirugikan akan kesulitan untuk melakukan klarifikasi. Berita hoaks juga 
bisa digunakan untuk mengalahkan kelompok tertentu dalam politik seperti pada saat Pilkada.

4. Munguntungkan Pihak Tertentu

Kasus kelompok pembuat berita profesional merupakan bukti nyata bahwa bisnis hoaks menggiurkan. Motif ekonomi bisa menjadi alasan penyebaran berita hoaks. Karena dengan menyebar berita hoaks, nominal yang diterima oleh kelompok ini akan besar.

5. Berita hoaks membuat fakta tidak lagi bisa dipercaya

Dengan semakin viralnya berita hoaks, fakta sebenarnya malah bisa dicap sebagai berita hoaks. Dengan ini masyarakat bisa kebingungan tentang fakta mana yang harus dipercaya. komunikasi dilakukan dengan tepat dan jelas. Berita hoaks bisa muncul dari komunikasi yang kurang tepat dan bisa membuat persepsi masyarakat menjadi buruk. 


\section{DAFTAR PUSTAKA}

Apriadi, Tamburaka. 2013. Literasi Media: Cerdas Bermedia Khalayak Media Massa. Jakarta: Raja Grafindo Persada.

Bungin Burhan. 2004. Metode Penelitian Kualitatif. Penerbit:PT Rajagrafindo Persada, Jakarta

David L. Altheide, and Christopher J. Schneider.1996. Qualitative Media Analysis. 2nd ed. v. 38. Los Angeles: Sage Publications

Dedy N. Hidayat. 1999. Paradigma dan Metodologi Penelitian Sosial Empirik Klasik, Jakarta : Departemen Ilmu Komunikasi FISIP Universitas Indonesia.

Denzin, Norman K. (eds). 2000. Handbook of Qualitative Research. California:Sage Public

Denzin, Norman K. dan Yvonna S. Lincoln (eds.). 2009. Handbook of Qualitative Research. Terj. Dariyatno dkk. Jogjakarta: Pustaka Pelajar

Eriyanto. 2001. Analisis Wacana: Pengantar Analisa Teks Media. Yogyakarta:LKIS

Guba, E.G \& Lincoln, Y.S (1994)." Competing Paradigms in Qualitative Research". In Denzin N.K. and Lincoln Y.S. (eds). Handbook of Qualitative Research, (pp. 1 05-117). New Delhi: Sage Publications.

Hall, Stuart. 1982. The Work of Representation. Theories of Representation: Ed. Stuart Hall. London. Sage publication.

L. Tubbs, Steward \& Sylvia Moss (editor; Deddy Mulyana). 1994.

Human Communication, Prinsip-prinsip Dasar. (Bandung; P.T. Remaja Rosdakarya; 1996)

Lasswell, Harold. 1960. The Structure and Function of

Communication in Society, Urbana: University of Illinois Press.

Lexy J. Moleong.2012. Metodologi Penelitian Kualitatif. Bandung: PT Remaja Rosda Karya

Littlejohn, Stephen W Littlejohn dan Karen A Foss. (2009). Teori Komunikasi, Theories of Human Communication, Edisi 9, Jakarta: Salemba Humanika 
Littlejohn, Stephen W. (1996). Theories of Human Communication.California: Belmont, Woodsworth.

Littlejohn, Stephen. 2002. Theories of Human Communication. California:Wadsworth Publishing Company

Littlejohn, Stephen. 2002. Theories of Human Communication. California:Wadsworth Publishing Company

McQuail, Denis.2005.Mass Communication Theory, 5th Ed. London: Sage Publications

Mulyana Deddy. 2005.Ilmu Komunikasi Suatu Pengantar. Bandung: PT Remaja Rosdakarya

Nana Syaodih Sukmadinata. 2011. Metode Penelitian Pendidikan. Bandung : PT Remaja Rosdakarya

Neuman, Lawrence W. 1997. Social Research Methods. London:Allyn and Bacon

Reese, Stephen D. 1991. Setting the media's Agenda: A power balance perspective, Beverly Hills: Sage.

Rogers, Everett. M. 1994. A History of Communication Study. New York:The Free Press

Shoemaker, Pamela cs (eds). 1991. Mediating The Message: Theories of Influences on Mass Media Content. London:Longman Group Sugiono.2007.Metodologi Penelitian Pendidikan Pendekatan kuantitatif, kualitatif. Bandung : Alfa Beta

Sukmadinata, N.S. 2011. Metode Penelitian Pendidikan. Bandung: Remaja Rosadakarya

Poespowardojo,Soerjanto\&Seran. 2015. Filsafat Ilmu Pengetahuan. Jakarta. Kompas Media Nusantara

Dokumentasi aplikasi whatsapp Triyono,Agus.2020

Dokumentasi aplikasi whatsapp Sumardi,2020

Dokumnetasi,Tularnalar,2020

Undang-Undang Nomor 19 Tahun 2016 tentang Informasi dan Transaksi Elektronik (ITE)

\section{Jurnal}

Juditha. Christiany. 2018 "Hoax Communication Interactivity in Social Media and Anticipation" (Interaksi Komunikasi Hoax di Media Sosial serta Antisipasinya). Jurnal Jurnal Pekommas, 
Vol. 3 No. 1, April 2018: 31-44. https://jurnal.kominfo.go.id/index.php/pekommas/article /view/2030104

Aminah. 2019. Dampak Hoax Di Media Sosial Facebook Terhadap Pemilih Pemula. Jurnal Komunikasi Global, Volume 8, Nomor 1 , 2019.

http://jurnal.unsyiah.ac.id/JKG/article/view/13565

Susilo, Edy.2020. "Perbandingan Pola Penyebaran Hoaks Antargenerasi. Jurnal Aspikom Vol 5, No 1 (2020). https://jurnalaspikom.org/index.php/aspikom/article/vie $\mathrm{w} / 533$

Triyono,Agus.2018. Peliputan Media Online Atas Kebijakan Politik Ri Terhadap Krisis Qatar Untuk Mendukung Diplomasi Internasional.Jurnal Egaliter.Vol 1, No 2. http://jurnal.unpand.ac.id/index.php/egr/article/view/90 2

Triyono,Agus.2019. Contribution of Online Media Citizen Journalism to Create City Images.Jurnal Ilmu Komunikasi, Vol 16, No 2 (2019), 209-224 http://ojs.uajy.ac.id/index.php/jik/article/view/1476 DOI: https://doi.org/10.24002/jik.v16i2.1476

Triyono,2020. A New Social Media Freedom Podcast Construction in the Millenial Generation. Proceedings of the 2nd Jogjakarta Communication Conference (JCC 2020). https://www.atlantis-press.com/proceedings/jcc20/125943398

https://doi.org/10.2991/assehr.k.200818.007

Triyono,agus.2020.Framing Analysis of Village Funding Corruption in Media Suaramerdeka.Com in Central Java, Indonesia, 2019 - Pages 1154-1163. DOI: https://doi.org/10.6000/1929-4409.2020.09.136 
https://www.lifescienceglobal.com/independent-journals/ international-journal-of-criminology-and-sociology/ volume-9/83-abstract/ijcs/4177-abstract-framing-analysisof-village-funding-corruption-in-media-suaramerdeka-comin-central-java-Indonesia-2019

\section{Website}

http://dispendukcapil.surabaya.go.id/berita/492-shirojutsu http:// pusbindiklat.lipi.go.id/id/hati-hati-terhadap-surat-palsupenipuan-yang-mengatasnamakan-lipi/

http://rekor-leprid.org/index.php/2019/07/17/lifetimeachievement-award-atas-prestasi-penemu-metode-cuciotak-brain-wash-dengan-modifikasi-program-digitalsubstraction-angiography-sda-untuk-penyakit-stroke-sejaktahun-2005/

https://cekfakta.com/focus/3978

https://cekfakta.tempo.co/fakta/702/fakta-atau-hoaks-benarkahdokter-li-enliang-dan-rs-di-cina-sarankan-minum-teh-bagipasien-corona

https://daerah.sindonews.com/artikel/jateng/7129/dokter-

terawan-raih-lifetime-achievement-award-dari-leprid https://m.rri.co.id/daerah/934211/hoak-pasar-gede-sololockdown-begini-sebenarnya

https://solo.tribunnews.com/amp/2020/11/23/awas-hoaksbanyak-pedagang-pasar-gede-solo-positif-corona-bakuldawet-langganan-jokowi-kena-catut?page $=$ all

https:// techcrunch.com/2020/03/16/youtube-warns-ofincreased-video-removals-during-covid-19-crisis/

https://turnbackhoak.id/2020/03/28/salah-salah-satu-solusiuntuk-virus-ini-adalah-secangkir-teh-sederhana/

https://wearesocial.com/

https://www.antaranews.com/berita/1394318/cek-fakta-tehdapat-enyembuhkan-covid-19-benarkah

https://www.facebook.com/birohumasdankeprotokolan/ https://www.instagram.com/dispendukcapil.sby/ 
https://www.instagram.com/p/B0p5GNgn-Xf/

https://www.instagram.com/p/B5HXns3DLPv/?igshid=8v0wx3 zz49u8

https://www.liputan6.com/cek-fakta/read/4414682/cek-faktatidak-benar-vaksin-covid-19-unfaedah-karena-pandemisudah-berakhir

www.jawapos.com

www.kominfo, 2020

www.lifestyle.okezone.com

www.maarifinstitute

www.mafindo.com

www.turnbackhoax.id 


\section{BIOGRAFI}

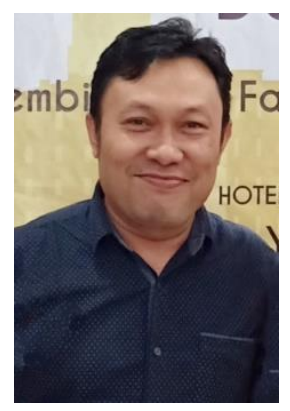

Agus Triyono, lahir di sebuah daerah yang diapit lingkungan Kasunanan Surakarta dan Keraton Yogyakarta. Tepatnya di daerah dekat obyek wisata pegunungan Deles Indah di Klaten, Jawa Tengah.Tanggal 02 Agustus pada hari Rabu Pon menjadi momentum yang berharga, karena tanggal tersebut pria ini dilahirkan. Dalam keseharian pria ini lebih akrab dipanggil dengan Agustri. Mengawali karir dari seorang reporter di radio Rasika FM Semarang tahun 1998-2001, kemudian hijrah ke Jawa Pos grup (Radar Semarang) tahun 2002 hingga 2011 dan juga menjadi wartawan Tabloid Agribisnis Agrina Jakarta tahun 20072011 untuk wilayah Jawa Tengah. Pernah memegang kendali Wapimred Tabloid suara KPK, Pimpinan Redaksi Potret Jateng.com. Dan, sekarang fokus menjadi seorang dosen di kampus favorit di Jawa Tengah yakni Universitas Dian Nuswantoro Semarang dengan konsen di bidang komunikasi media. Menulis masih menjadi hobby hingga kini, tak heran tulisannya sering dimuat di media massa.

Organisasi yang telah digelutinya antara lain sebagai Pembina organisasi Perhimpunan Hubungan Masyarakat (Perhumas) Kota Semarang, Anggota Pengurus Asosiasi Perguruan Tinggi Ilmu Komunikasi (Aspikom) Pusat bidang Pengembangan Laboratorium. Sekretaris bidang Humas dan Kerjasama Masjid Agung Jawa Tengah. Kini, aktif sebagai Relawan Anti Fitnah Indonesia (MAFINDO). 
Menikah dengan Susi Hariyani, dan dikarunia 2 putra dan 1 putri, Mereka adalah Muhammad Afif Ridwan Adham, Rizqy Bintang Malika dan Aleena Nafisa Pramadhita.

Hidup harus memberi manfaat untuk orang lain adalah moto hidupnya. Oleh karenanya ia sangat menyukai berbagai kegiatan yang berorientasi pada kemahaslatan orang banyak. $\left({ }^{*}\right)$ 